\title{
The Effects of the Far-Infrared Ray (FIR) Energy Radiation on Living Body
}

\author{
Kikuji Yamashita
}

Additional information is available at the end of the chapter

http://dx.doi.org/10.5772/36005

\section{Introduction}

\subsection{A far infrared ray (FIR) energy}

The power of the energy radiated from any material is dependent on the temperature. For example, the sun with the temperature of $6,000^{\circ} \mathrm{C}$ at the surface and $\sim 15,000,000^{\circ} \mathrm{C}$ at the depths radiates the radio-magnetic ray with from the weak to the strong energy. The radiomagnetic ray with strong energy is absorbed before the arrives at the surface of the earth. But, if a human bathe in the ultraviolet ray even if it arrives only about $0.6 \%$ of whole ultraviolet ray radiated by the sun, the surface of skin is burned and strongly damaged. If the cell is poured the large quantities of ultraviolet ray, the DNA of nuclear is injured to induce a liver spot, freckles and aging of skin. Still more, it is thought that the immunity is inhibited and a cataract and a skin cancer can be induced by the ultraviolet ray. It was thought that the sunlight arrived at the surface of earth was finally composed of the ultraviolet ray (UVA, UVB) of $6 \%$, the visible ray of $52 \%$ and the infrared ray of $42 \%$. It was well known that the energy of these lights bring a lots of the good effects for living bodies. The other sides, the materials on the earth we are living radiated the narrow range of energy from 5 to $50 \mu \mathrm{m}$ in FIR under $30^{\circ} \mathrm{C}$ by getting the energy of sunlight.

In other words, thought the radiating energy on the earth creating a life was only FIR of $5 \sim 50 \mu \mathrm{m}$ by getting the energy of visual ray and FIR, the earth was filled with the energy of only FIR of narrow range. It was means that the energy of FIR may make contribution to the birth of a life. The National Aeronautics and Space Administration (NASA) reported which ray indispensable for the maintenance of the life was FIR of $4 \sim 20 \mu \mathrm{m}$ as the artificial sun in the space station. Therefore, it comes to a conclusion that the FIR is the raising ray for the living body (Fig.1). Recently, there have been many studies of the effects of FIR on health and food preservation. The available evidence indicates that whole-body FIR irradiation has 
biological effects [1-7]. Whole-body FIR irradiation is believed to improve human health and sleep by enhancing blood circulation in the skin [1,2]. However, the effects of FIR on cells are not clearly understood. These thinking let me realize that there are a lot of natural materials radiating strongly the energy of FIR as a charcoal, stone, soil and tree. So, these natural materials were being used for our studies on the energy of FIR.

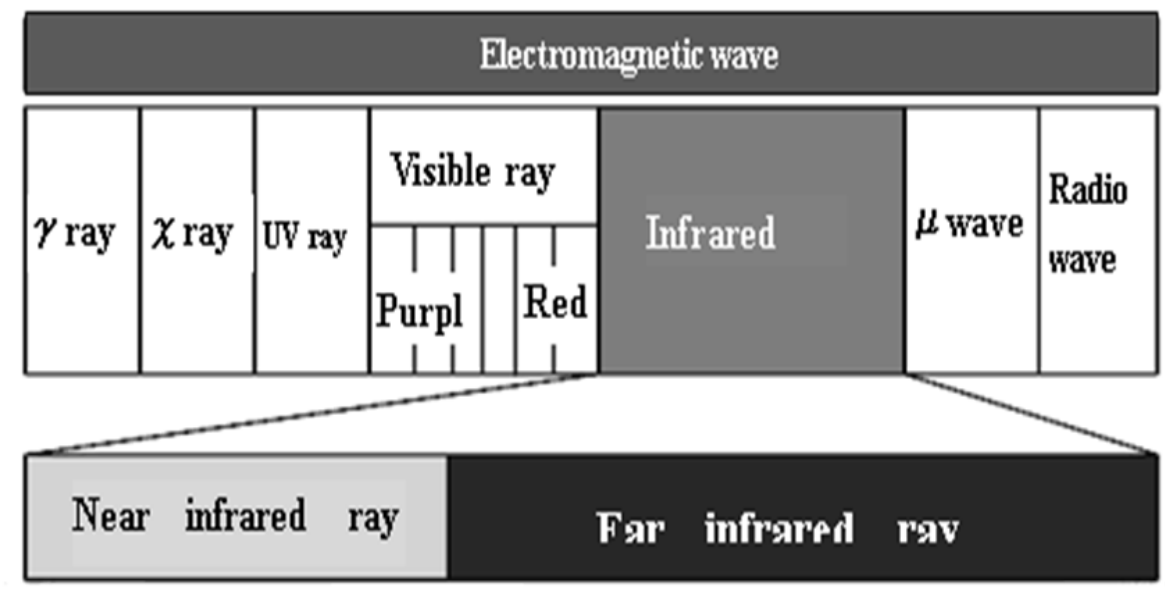

$0.74 u m$

4um

$1000 u m$

Figure 1. The classes of the electromagnetic wave by the wave length $\mu \mathrm{m}$

\section{The characteristics of rhyolite}

In order to study strictly the effects of the energy of FIR in $4 \sim 20 \mu \mathrm{m}$ on the living body, the radiating machine of the energy of FIR should be developed. In order to develop it, the selection of a good FIR radiator were started at first. The most noticeable effect of FIR energy radiation was the activation of water molecules. The change of the weight of the ultrapure water on the FIR ceramics containing the five natural stones, 4 chemical products of mineral oxide and charcoal was exactly measured with time at $37^{\circ} \mathrm{C}$. Though it was made clear that some natural stones activated the evaporation of pure water, the rhyolite especially strongly activated. Then, the rhyolite (MATERA Inc. Toon, Ehime, Japan) mined at Toon, Ehime in Shikoku Island was selected as the FIR radiation ceramics for the development of the radiating machine of the energy of FIR (Fig.2). The characteristic of rhyolite was the volcanic rock containing $70 \%$ over silicate dioxide with the flowing patterns formed by the phenocryst of magma (Fig.2). Though the components are the quartz, feldspar and biotite, the rhyolite is similar the granite. When the FIR energy radiated from the rhyolite was measured by Fourier transformed infrared spectrophotometer, it was made clear that the rhyolite was radiated $90 \%$ over the ideal black body at whole range of $5 \sim 20 \mu \mathrm{m}$ (Fig.3). It was proved that the rhyolite was the excellent radiator of FIR energy of 5 20 $\mu \mathrm{m}$. 


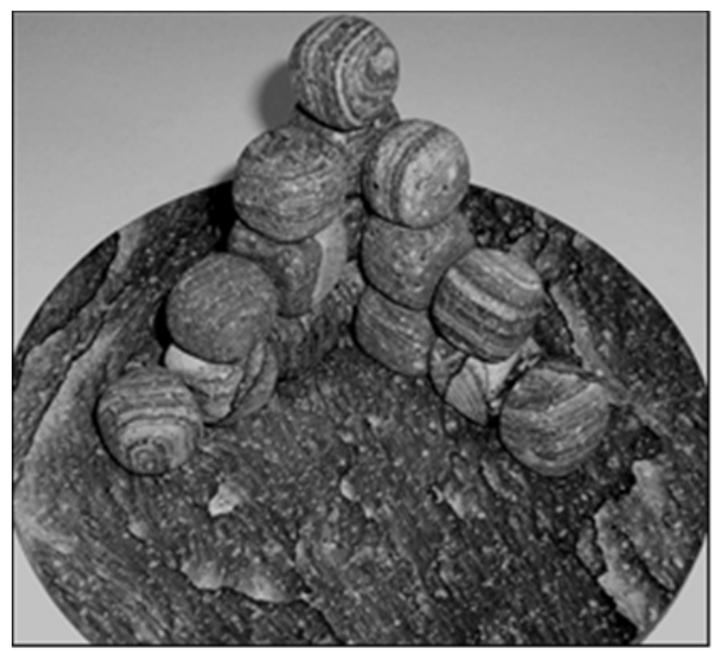

Figure 2. The photograph of the rhyolite

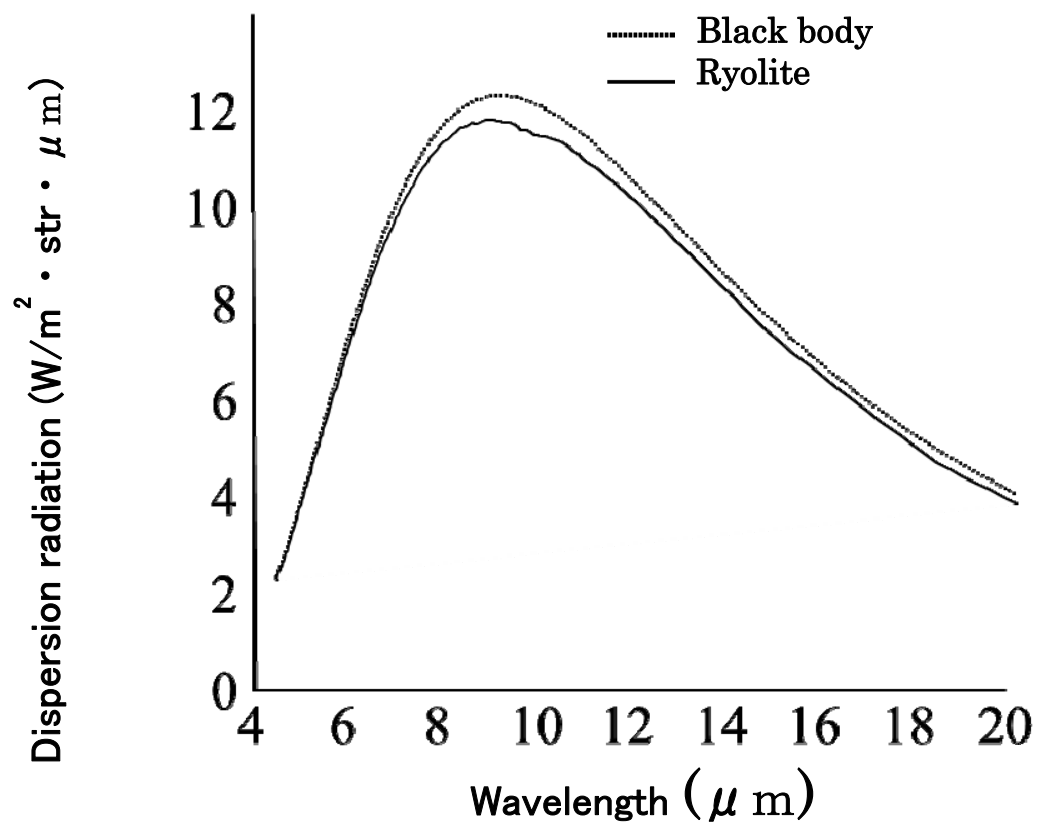

Figure 3. The radiation energy of the far infrared ray from the radiator

The powder of rhyolite showed the antibacterial action to the Staphylococcus aureus ATCC6538P at $1 / 5012$. The adhesive sheet with the $15 \%$ powder of rhyolite showed at $1 / 1995$. Still more, the paint containg the $10 \%$ powder of rhyolite showed the antibacterial action to the Methicillin-Resistant Staphylococcus Aureus MRSAIID 1677 at 1/5012. 
The values of antibacterial action of the materials containing rhyolite are respectively 3.7, 3.3 and 3.2. Though the values of antibacterial action over 2.0 was estimated as the antibacterial substance, the rhyolite was regarded to be the fairly mighty the antibacterial substance. Still more, the antibacterial action of rhyolite to the colon bacillus was verified in neutral condition at our laboratory also (Fig.4, Table 1). These results suggested that the antibacterial action of rhyolite did not depend on the change of $\mathrm{pH}$. This graph showed the effects of rhyolite on the oxidation-reduction potential of water (Fig.5).

\begin{tabular}{|c|c|c|c|}
\hline Item & $\begin{array}{l}\text { The water } \\
\text { treated with the } \\
\text { powder of } \\
\text { rhyolite }\end{array}$ & $\begin{array}{l}\text { The water } \\
\text { treated with the } \\
\text { stone of rhyolite }\end{array}$ & Control \\
\hline $\begin{array}{l}\text { Biochemical oxygen demand } \\
\mathrm{mg} / 1\end{array}$ & 2.1 & 2.4 & 2.4 \\
\hline Chemical Oxygen Demand mg/1 & 3.4 & 3.9 & 3.9 \\
\hline Suspended solids & 12 & 10 & 8 \\
\hline Dissolved Oxygen & 9 & 8.9 & 9.1 \\
\hline $\begin{array}{l}\text { Escherichia coli group number } \\
\text { MPN/100ml }\end{array}$ & 0 & 2200 & 14000 \\
\hline Conductivity & 18.6 & 19.5 & 19 \\
\hline
\end{tabular}

Table 1. The chemical analysis of the rhyolite treated water

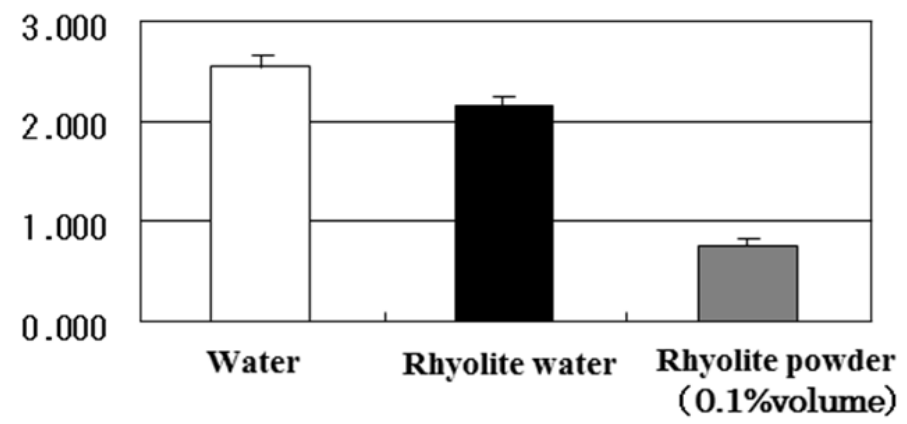

Figure 4. The effect of the rhyolite on Escherichia coli; Escherichia coli (DH50) were cultured for 16 hours in the sterilized pure water, the water containing the rhyolite and the water containing $0.1 \%$ rhyolite powder. The proliferation of the Escherichia coli inhibited at $15.6 \%$ in the water containing the rhyolite and $69.9 \%$ in the water containing $0.1 \%$ rhyolite powder. 


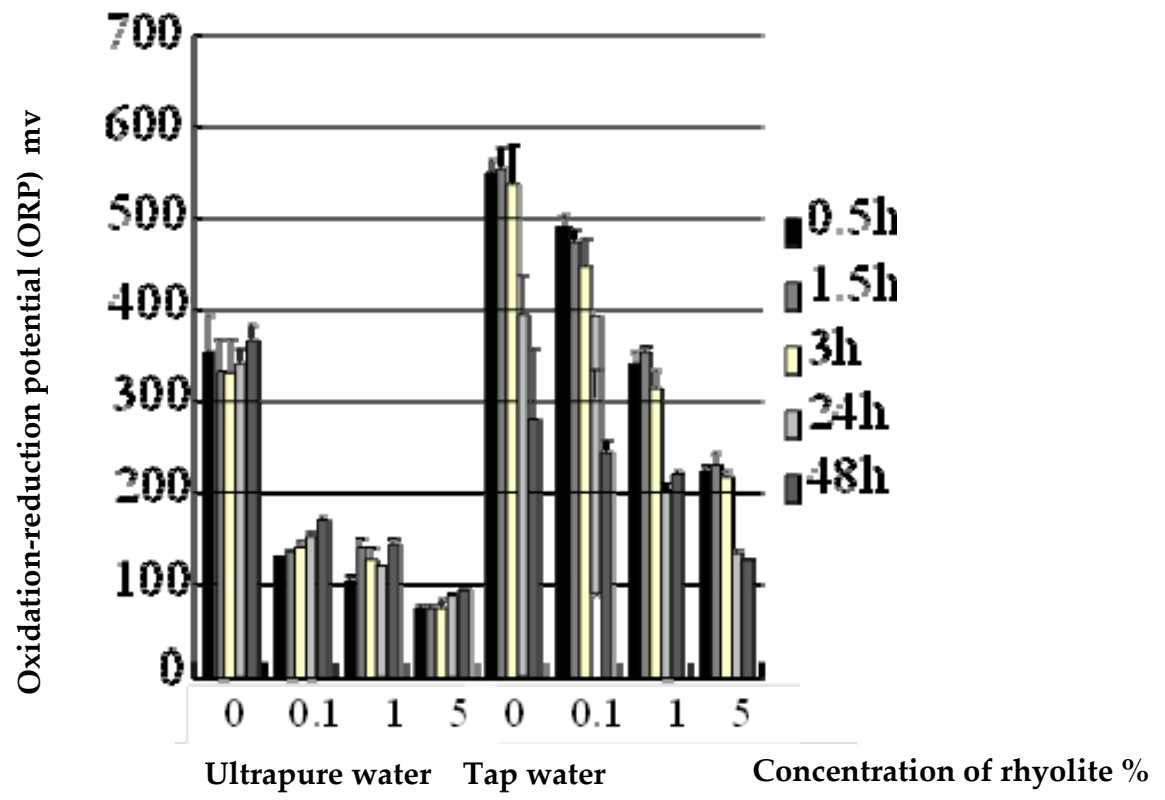

Figure 5. The change of the oxidation-reduction potential affected by the rhyolite. The oxidationreduction potential (The longitudinal axis shows ORP, mv) decreased depending on the contents of the rhyolite(The transverse axis shows \%) after 0.5-48h.

Though the oxidation-reduction potential of tap water is about 550, it decreased with time to be about 280 after 48 hours. When the powder of rhyolite was put into tap water at $0.1 \%, 1 \%, 5 \%$, the oxidation-reduction potential of tap water decreased respectively up to 480,340 and 220. Then, it decreased with time up to about 130 after 24 hours. It was thought that the high oxidation-reduction potential of the tap water caused by the residual chlorine. The reason why the oxidation-reduction potential of the tap decreased with time might be that the hypochlorous acid in tap water evaporated as the gas of chlorine with time. The oxidation-reduction potential decreased in the dependent upon the density of the rhyolite powder. It was thought that the reason was by the elution of any reducing agent from rhyolite. The small amounts of any elements with oxidative reaction were left in the ultrapure water. Therefore, the small amounts of rhyolite powder could reduce the most of oxidizers in the ultrapure water. The mighty oxidative powers of the residual chlorine attack the cell membrane of a microorganism and a virus to degenerate the inner protein and show the germicidal and disinfectant effects. It was thought that the reducer generally do not show a mighty antibacterial effect. Why the rhyolite shows the mighty antibacterial effects? Then, the $500 \mathrm{~g}$ of rhyolite powder was put into 11 of ultrapure water. After keeping 18hours, the supernatant of the water was collected and filtrated with the filtering paper. Still more, the filtrate was centrifuged at 
$3000 \mathrm{rpm}$ for $10 \mathrm{~min}$. The supernatant of $600 \mathrm{ml}$ dried at $200^{\circ} \mathrm{C}$ for 5 hours up to get $13.4 \mathrm{mg}$ of white precipitates. The precipitates were analyzed by the $x$ ray diffraction and the electron-micro analyzer. The results showed that the precipitates mainly consist of calcium and silicon (Fig.6). As the rhyolite contained $70 \%$ over silicate, the results suggested that the ceramics structure consist of silicate oxide should disintegrate. Then, the silicate radical molecule containing an additional electron could be formed. It was thought that the radical molecules are so active that the bacterium el.al was contacted to collapse the cell membrane with an antibacterial action. Though the mechanism to form the silicate radical molecule was not clear, the antibacterial effects of the rhyolite containing the $70 \%$ over silica were the experimental facts.
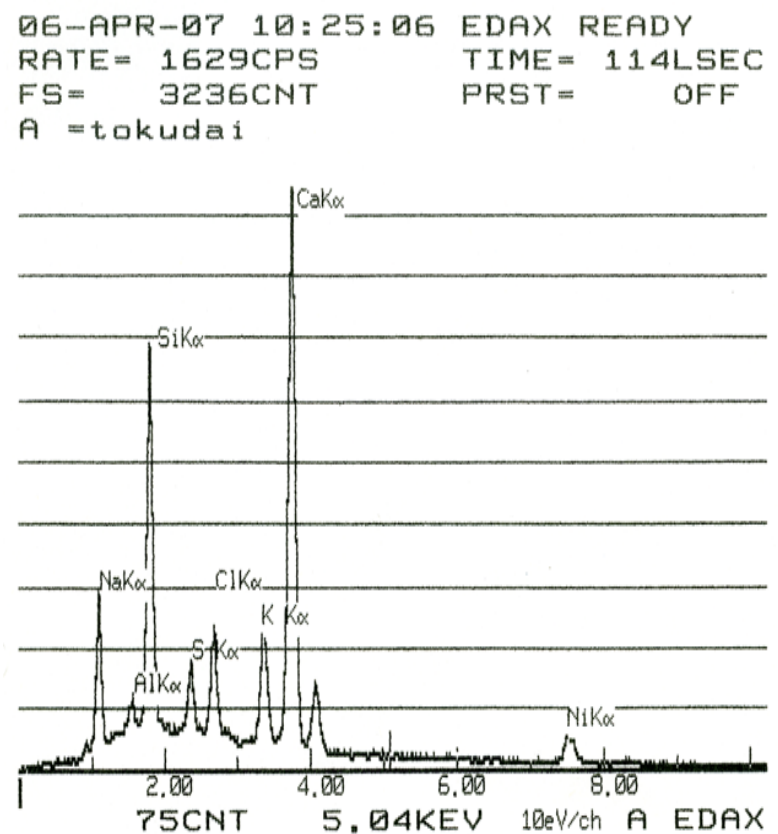

Figure 6. The analysis by the $x$ ray diffraction of the components in the solution

\section{The development of the FIR energy radiator}

In order to clarify the effects of the FIR energy radiation on the living body at the rebel of a cell and animal, the FIR incubator for cell culture and animal raising apparatus was developed utilizing the valid ceramics as the rhyolite and the pureblack that the resemble effects as the ideal black body are well known.

The $\mathrm{CO}_{2}$ incubator must be exactly controlled the temperature inside of the incubator at $37 \pm 0.5^{\circ} \mathrm{C}$. Therefore, though the water jacket of about 40litter is equipped for the suppression 
of heat loss, the equipment of incubator becomes solid and heavy. Then, $0.5 \% \mathrm{CO}_{2}$ gas need be supply into the incubator to activate the culture cell breathing. Still more, the gas of $0.5 \%$ $\mathrm{CO}_{2}$ in air must be supplied though the water layer in order to keep the humidity near $100 \%$. So, we remodel the existing $\mathrm{CO}_{2}$ incubator. The heating system was changed to FIR panel heater for keeping the temperature in the incubator at $37 \pm 0.5^{\circ} \mathrm{C}$. The five face at up, down, both side and behind in the incubator except the front glass were coated with the valid ceramics as the rhyolite and the pureblack close to black body for raising the efficiency of FIR radiation. The all shelves were also coated with the same ceramics. Still more, the water jacket was change to the simple insulation, because the FIR energy directly and instantly heats the surface of objects even if the air and space lie between the surface of incubator and the objects. As a result, the light and compact $\mathrm{CO}_{2}$ incubator that can continuously radiate the FIR energy for 24 hours was developed with a great success (Fig.7) [8]. So, the strict comparative experiments on the effect of the FIR energy radiation on the culture cells become possible utilizing the same type of $\mathrm{CO}_{2}$ incubator without remodeling as control.

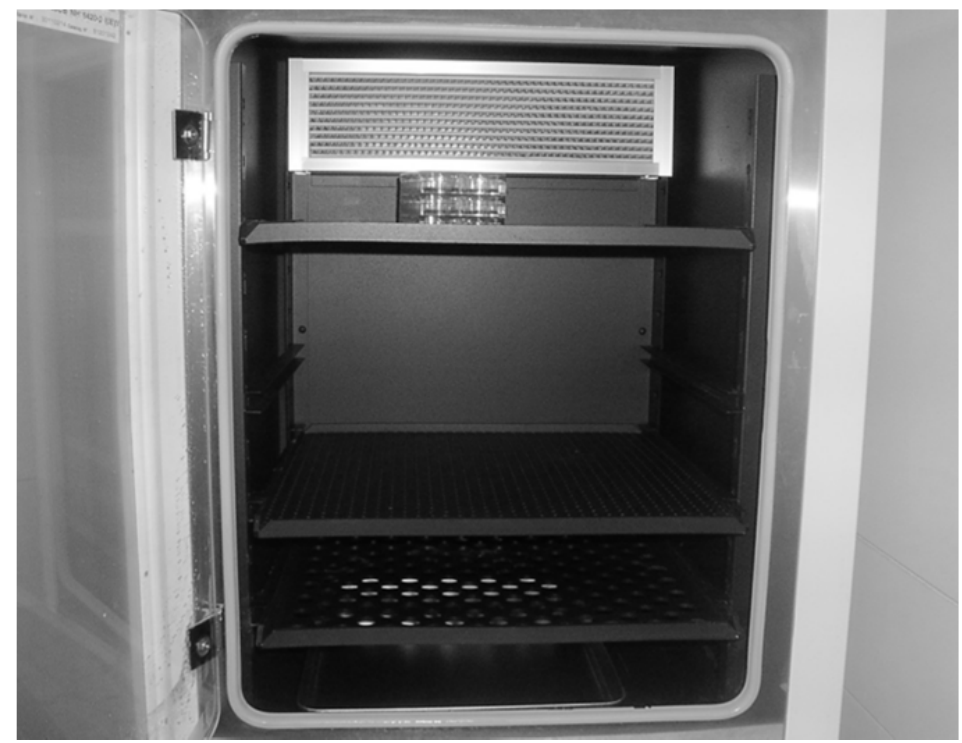

Figure 7. The $\mathrm{FIR}_{2} \mathrm{CO}_{2}$ incubator

Then, the FIR animal raising apparatus with same FIR radiating system of the FIR $\mathrm{CO}_{2}$ incubator to control the temperature inside $20-40^{\circ} \mathrm{C}$ at will and break down any smell chemical products by photo-degradation with the light catalyst of $\mathrm{TiO} 2$ could be also developed (Fig.8). The FIR animal raising apparatus has the two chambers which the upper chamber is coated with the valid ceramics as the rhyolite and the lower chamber is no coating [9]. So, the strict comparative experiments on the effect of FIR energy radiation on animals become also possible by using the FIR animal raising apparatus. 

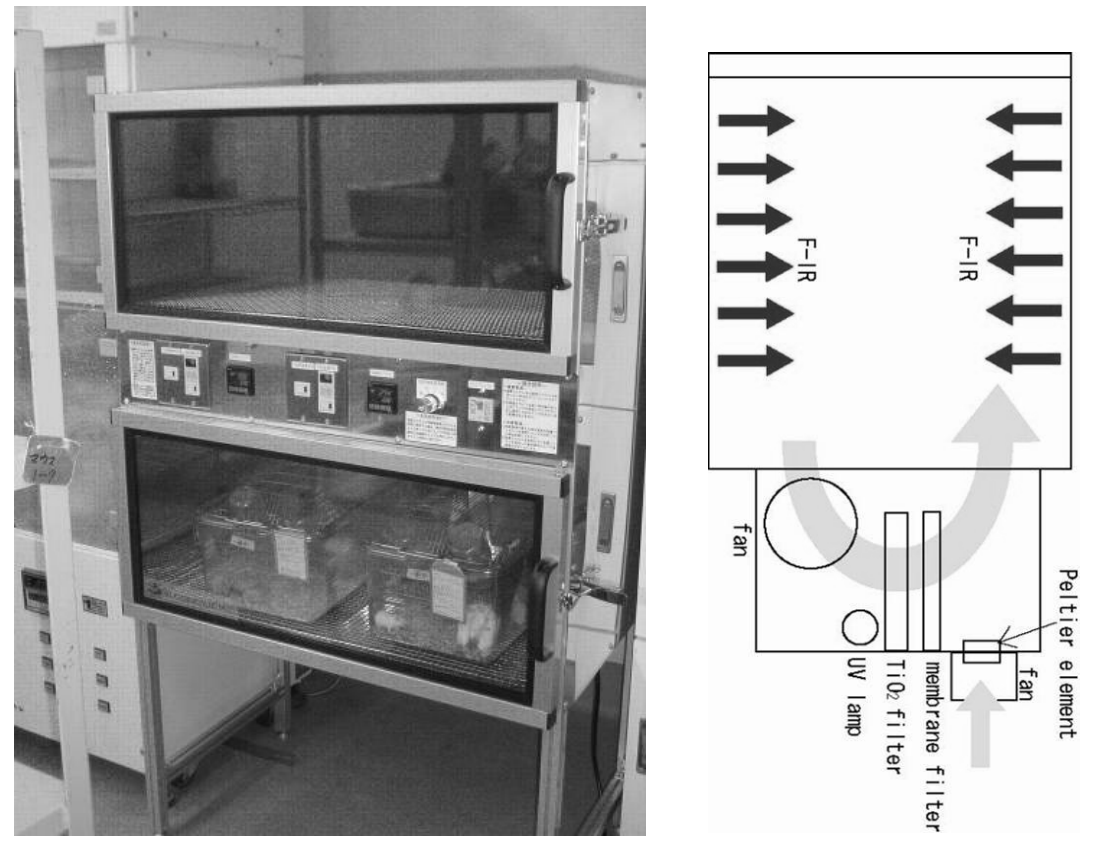

Figure 8. The FIR animal raising apparatus

\section{The effects of FIR energy radiation on water}

\subsection{The volatility and fluidity of water}

Water is indispensable for human life. As water is generally present surrounding us, the characteristics of water is hard to be considered as a strange matter. But, the truth that a boiling point of water is $100^{\circ} \mathrm{C}$ is peculiar comparing with the other elements with the similar molecular weight. For examples, though a sulfur is next of oxygen in the periodic table of the elements, the boiling point of hydrogen sulfate $\left(\mathrm{H}_{2} \mathrm{~S}\right)$ is $-60.7^{\circ} \mathrm{C}$. But, as the molecular weight of oxygen is smaller than that of sulfur, the boiling point must be smaller than $-60.7^{\circ} \mathrm{C}$. It is supposed that the boiling point of water should be theoretically at about $-80^{\circ} \mathrm{C}$. Then, the coagulating point of water is appropriate theoretically at about $110^{\circ} \mathrm{C}$. Well, why the boiling and coagulating points are respectively at $100^{\circ} \mathrm{C}$ and $00^{\circ} \mathrm{C}$ ? The reason is by the formation of cluster through the pulling against each other among the water molecules by a hydrogen bond et al. The imaginary molecular weight inferred from the boiling and coagulating points is about 100 by which 5, 6 water molecules gathered. Then, a water molecule has as much as four hydrogen bonds. Moreover, it was thought that the shapes of the cluster shows a straight chain, from a square to eleven-cornered shape, and the average shape is the pentagon. Moreover, it was thought that the cluster of water is not stable for long time, but it was formed and broken at the cycles of $10^{-12}$ seconds. But, this condition of cluster is only applied to the very pure water without any 
ion and impurity. The real water actually contained various impurities. Even if the very pure water is kept in air, the condition of water changes moment by moment by melting of a gas and molecules from air. Then, in order to estimate the present conditions of energy in the water, the change of the weight of water is exactly measured for the indicator of the volatility. When the difference of volatility between the tap water and the deionized water are compared, the deionized water is clearly volatilized more quickly than the tap water (Fig.9).

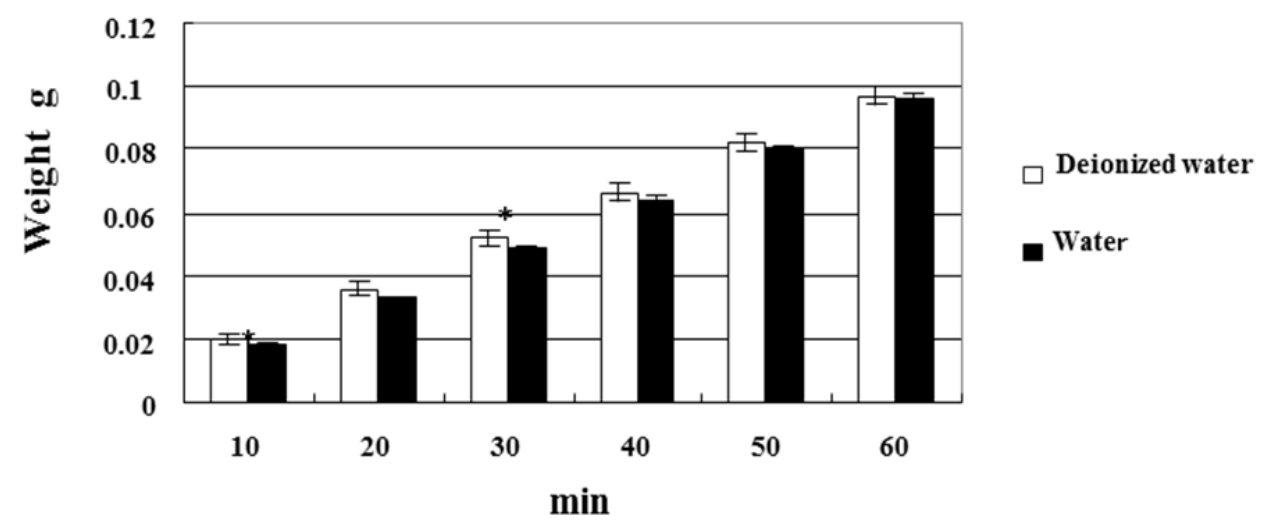

Figure 9. The change of the weight of the deionized water and the tap water

The high volatility means that a lot of water molecules spring out of the surface of water. Therefore, it is supposed that the energy of the water molecules is high and its cluster is small. This graph shows the change of weight of the deionized water radiated FIR energy through the grass layer by keeping in the FIR incubator for 12 hours and the untreated deionized water (Fig.10). Though the deionized water more quickly losses the weight than the tap water, the deionized water radiated FIR energy losses much bigger weight than the deionized water. In other words, it was made clear that the deionized water radiated FIR energy has high energy in the molecules to evaporate much easy. The results mean that the cluster of the water can become small by the FIR energy radiation. If that is the case, why the cluster formed by the water molecules changes by accepted the FIR energy? The water molecule consisting of two [O-H] bonds opening with $104^{\circ}$ has three types of the vibration energies. One is the deformation vibration of $1594 \mathrm{~cm}^{-1}$ and the others are the symmetrical and asymmetrical expansion and contraction energy of each $3656 \mathrm{~cm}^{-1}$ and $3756 \mathrm{~cm}^{-1}$. When the energy were convert to the wave length, the deformation vibration is $6.27 \mu \mathrm{m}$ and the expansion and contraction energy are $2.74 \mu \mathrm{m}$ and $2.66 \mu \mathrm{m}$ [10]. If the FIR energy of $5 \sim 20 \mu \mathrm{m}$ radiated the water molecules, the deformation vibration of the water molecule was activated by the transmission of the energy through the resonance effect because the energy of deformation vibration was coincident with the radiating energy. Consequently, it was thought that the kinetic energy 
of the water molecule increased to rush out of a cluster. The cluster in the activated water by FIR energy radiation ought to raise the volatility. On the contrary, the strength of FIR energy radiation by any materials can be estimated by measuring the change of the volatility. Then, when the boiling points of water was measured, that of FIR radiated water was $97.4^{\circ} \mathrm{C}$ and that of control water was $98.9^{\circ} \mathrm{C}$. The boiling point of water decreased clearly by FIR energy radiation. These results also suggested that the water molecules are at the condition to rush out easy from the surface of water. Still more, when the viscosity of water was measured, it was clarified that the viscosity clearly decreased by the FIR energy radiation (Fig.11). These results also suggest that the water become to flow easy by the same change of the cluster in water. It is thought that the water radiated FIR energy increases the volatility and fluidity at the same time. It is a very important finding. For example, it is thought that the blood and lymph flow in the human body become smoothly and activates by radiation of the FIR energy. It is only natural that the collection of lymph fluid into a lymph vessel rides the swelling in the body. Then, a tear, sweat and digestive juices become similarly to flow easy also. It is suggested that the activation of the secretion of a tear stimulate the para-sympathetic nerve system. Still more, the activation of the secretion of a sweat stimulates the various metabolisms in whole body. The activation of the secretion of the saliva and digestive juices stimulates the digestive function to make the body vigorously.

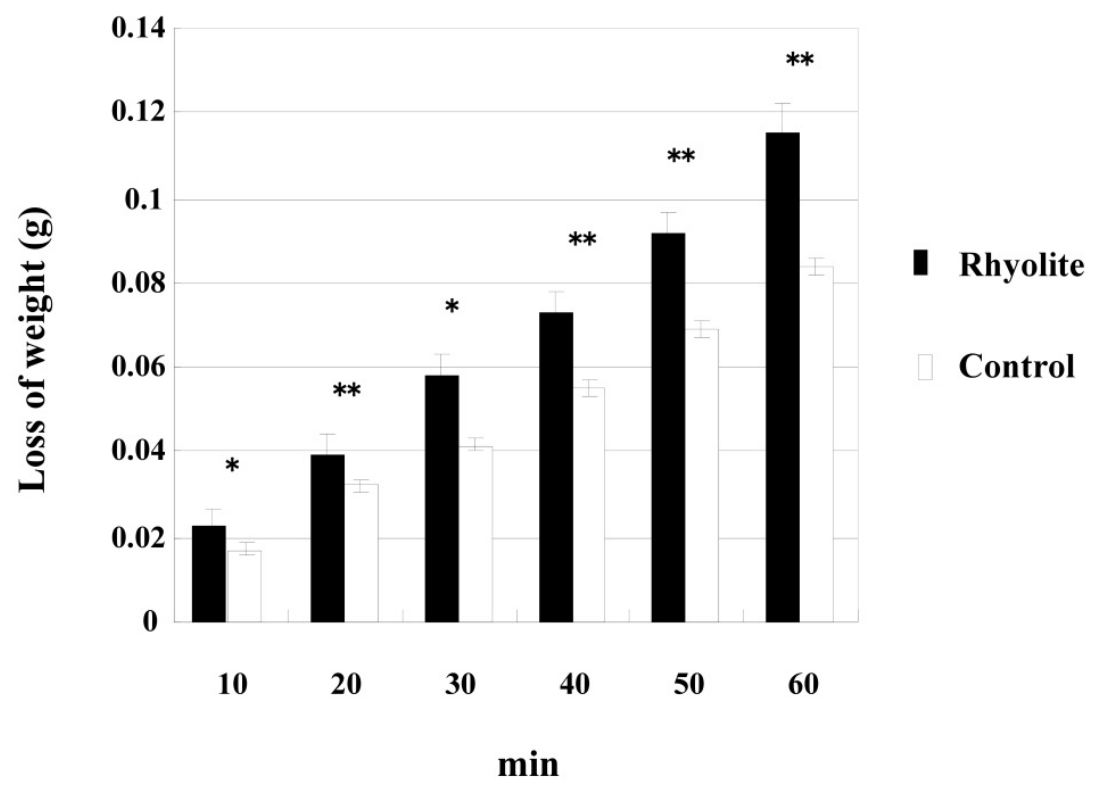

Figure 10. The change of the deionized water weight affected by the rhyolite as the FIR radiator 


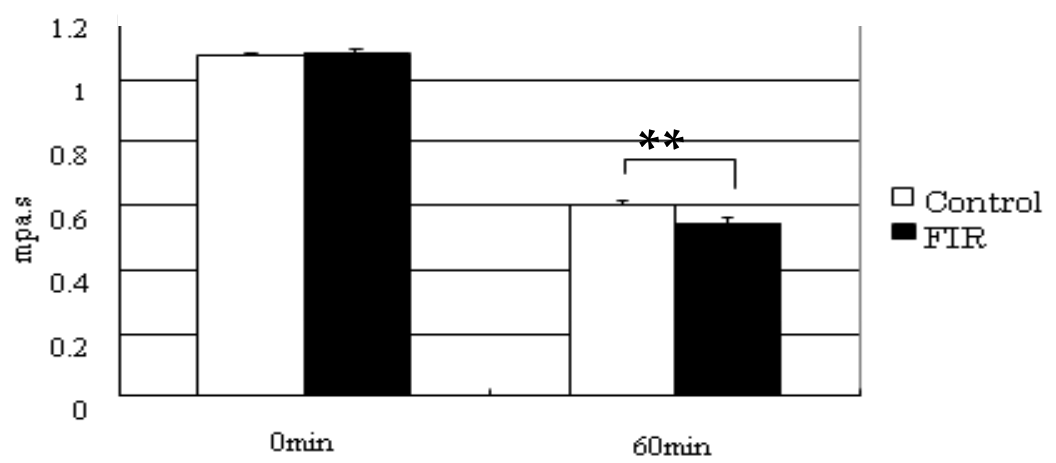

Figure 11. The change of the viscosity of water by the rhyolite as the FIR radiator

\subsection{The solubility of water}

It was found that the water radiated FIR energy by the rhyolite become to dissolve variable products. The plastic culture dish adhered proteins as bovine serum albumin (BSA) were prepared for the estimation of the solubility of water. The FIR energy radiated ultrapure water by the rhyolite and non-treated same water poured into the dish, and was collected for measurement of the UV absorbance for protein. The results showed that the FIR energy radiated ultrapure water could dissolve much more BSA than the non-treated same water (Fig.12). Not only protein but also sugar and sodium hydroxide were checked the solubility. The results showed that the FIR energy radiated ultrapure water could dissolve much more them. When the rhyolite powder was inserted into a fish tank at about $0.5 \%$, the water in the tank became clear just after 4 days. These results were considered by which the deposited protein and other products in the tank dissolved in water to raise the degree of transparency by the FIR energy radiation from the rhyolite. It was confirmed that the fishes and shell fishes become live longer than usual and keep the freshness in the tank with the rhyolite. For the application of these effects of the FIR energy radiation on water, the development of the contact lens cleaner was tried. The force of cleaning in the FIR energy radiated ultrapure water were estimated to the contact lens attached the BSA on the surface. The results suggested that the force of cleaning of water was surely raised by FIR energy radiation from rhyolite. But, as the force of FIR was defeated to a detergent, the development of the contact lens cleaner was given up. However, it was expected that the effects of the FIR energy radiation from rhyolite, on which the force of solubilizing in water was activated, will be applied in various fields in future. 


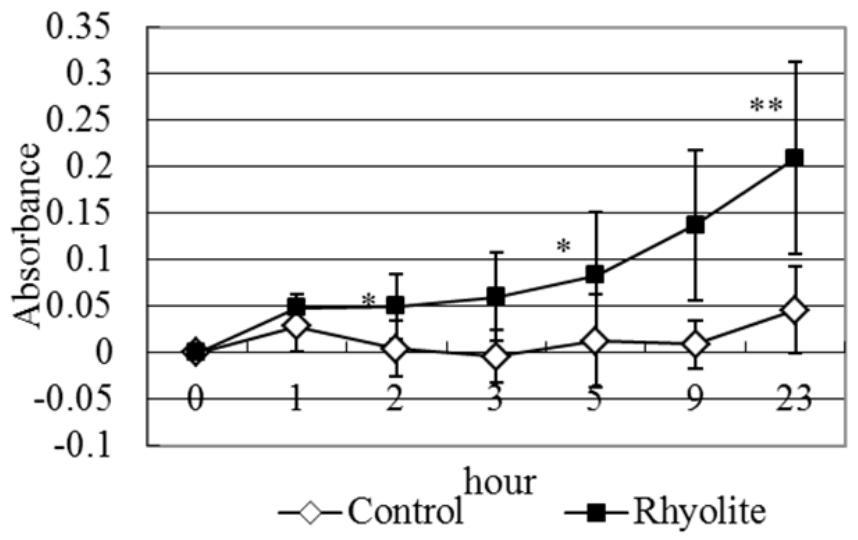

Figure 12. The solubility of BSA in the FIR energy radiated water

\section{Experiment}

\subsection{The effects of the FIR energy radiation on an animal}

\subsubsection{The effect of the FIR energy radiation on the change of body weight of an animal}

When the rats were raised by using the FIR animal raising equipment, the increase of the body weight of rats radiated FIR energy became gentler than that of control (Fig.13). Though the same experiments on the body weight of rats repeated five times, the results showed the same tendency that the FIR energy radiation inhibited the increase of the body weights. In some laboratories, the rats and the mice eat foods and drink water as much as wish. As a result, the rats and the mice naturally grow fat within a year. Therefore, it should be thought that the FIR energy radiation activates the exercise activity and keeps away the switchover to the obesity conditions.

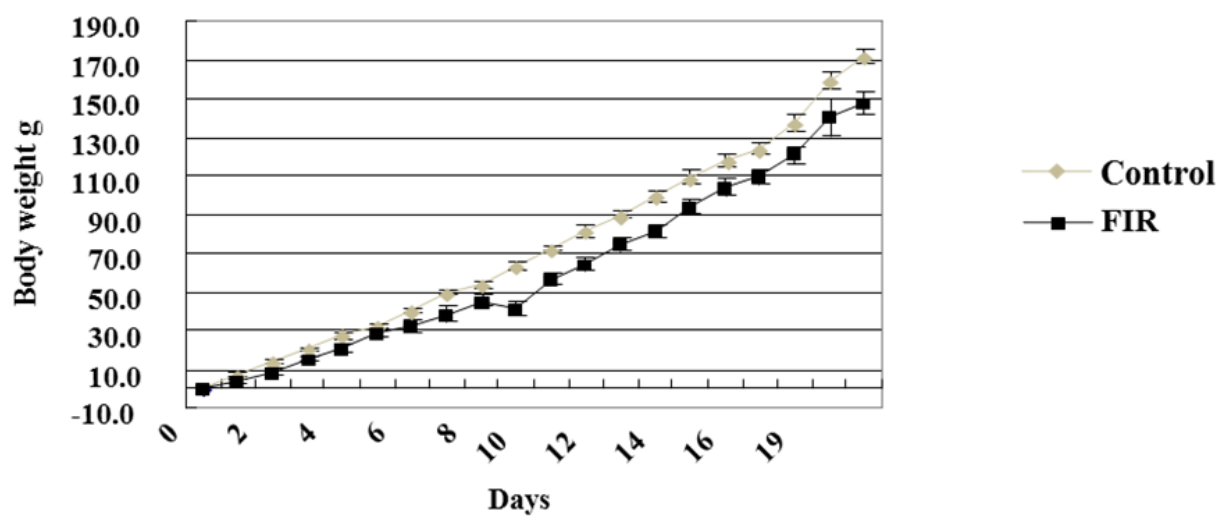

Figure 13. The change of the body weight affected by FIR. The growth of the rats was inhibited by the rhyolite as the FIR radiator. 


\subsubsection{The effect of the FIR energy radiation on the change of blood flow of an human}

The Rhyolite powder with a peak diameter of about $10 \mu \mathrm{m}$ was printed to the blanket cloths made in Japan at 15\%, like polka dots of about $2 \mathrm{~cm}$ (MATERA Inc. Toon, Ehime, Japan). The Rhyolite containing blanket and the control blanket were applied to the healthy volunteers for application of FIR energy of $20 \mathrm{~min}$ at room temperature $22^{\circ} \mathrm{C}$ and room humidity $50 \%$, after acclimation of the condition in the room for $10 \mathrm{~min}$. The velocity and the quantity of blood were continuously measured by the laser Doppler blood perfusion monitor and imagers in the same way for $20 \mathrm{~min}$. The order of the application between the FIR and the control blankets was often changed at the condition of double blind. The velocity and the quantity of blood flow were accelerated 32.2\% (Fig.14) and 19.1\% (Fig.15) by the application of the Rhyolite containing cloths.

Blood catecholamine at the time of the towel use

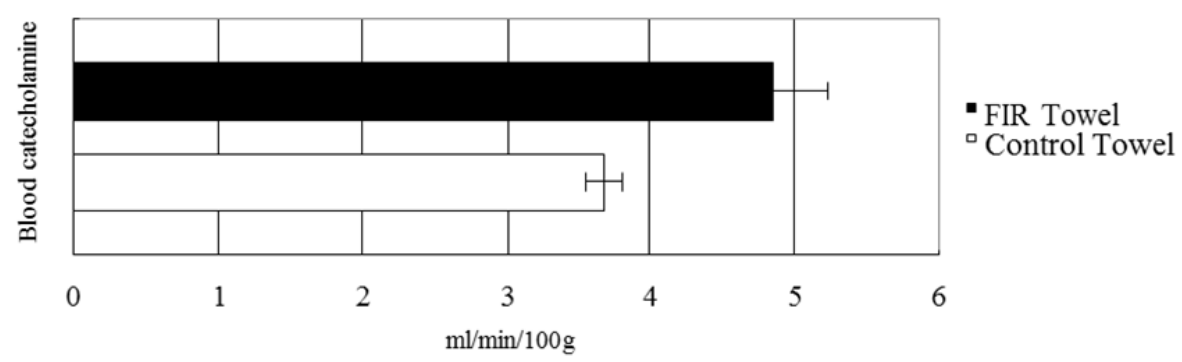

Figure 14. The change of the velocity of blood by the FIR blanket. This graph showed the velocity of the blood after $60 \mathrm{~min}$ of using the rhyolite containing blanket. The velocity of the blood increased $32.2 \%$ in the rhyolite containing blanket compared with the control blanket.

Blood stream at the time of the towel use

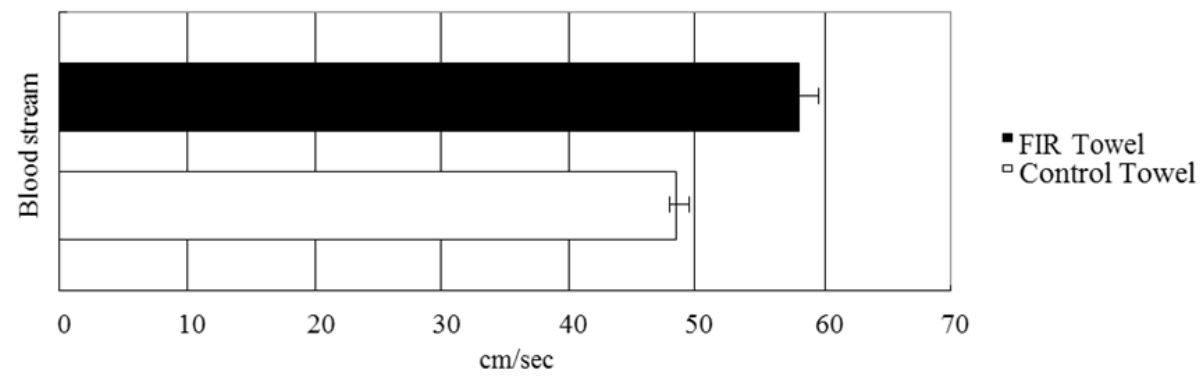

Figure 15. The change of the quantity of blood by the FIR blanket. This graph showed the quantity of the blood after 60 min of using the rhyolite containing blanket. The quantity of the blood increased $19.1 \%$ in the rhyolite containing blanket compared with the control blanket. 


\subsubsection{The effect of the FIR energy radiation on the change of blood catecholamine}

The amount of adrenaline, noradrenaline and dopamine in blood of the 40 mice keeping in the FIR and control animal raising apparatus for 40 days were measured at the blood center. It was shown that the amount of the dopamine in blood catecholamine significantly decreased, and the adrenaline and the noradrenaline in the blood catecholamine tend to decrease by radiated the FIR energy (Fig.16). These results suggested that the FIR energy radiation decreased the amount of the blood catecholamine in mice to inhibit the sympathetic nerve and activate the parasympathetic nerve. A mamma as a human body has the autonomous nervous system with the motor nervous and sensory nervous system. The autonomous nervous system distributes all internal organs to work in order to sustain a person's life independent of his mind.

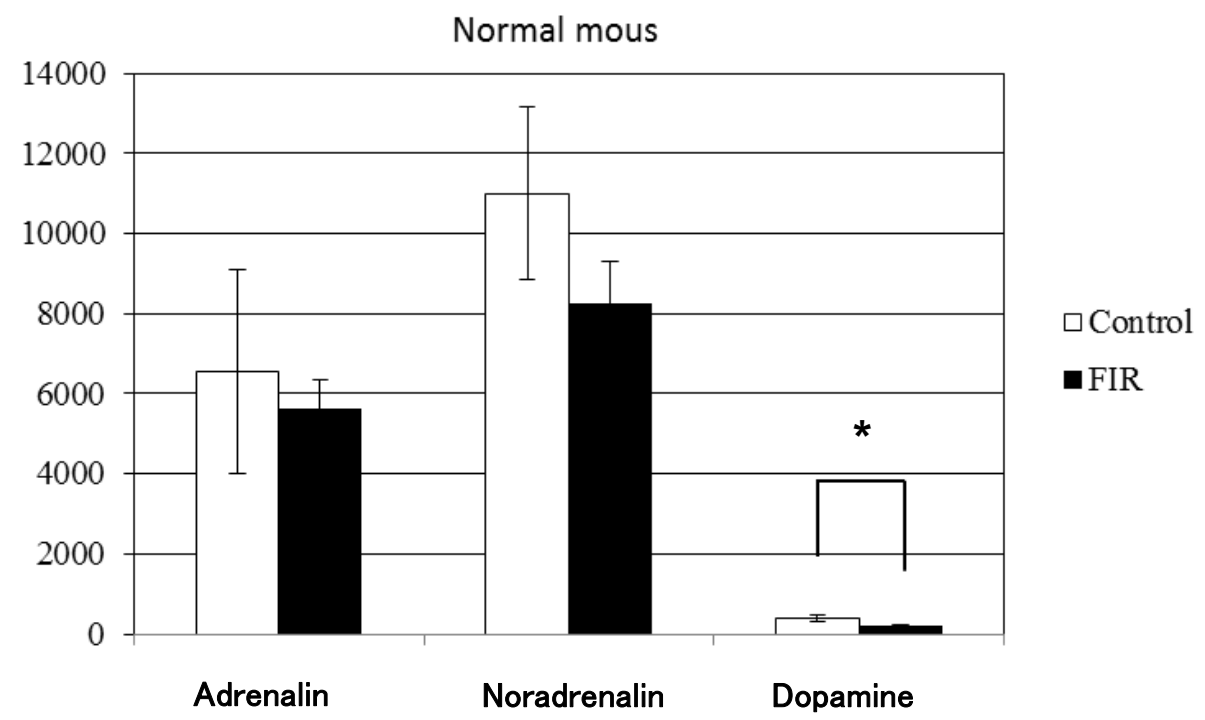

Figure 16. The change of the concentration of catecholamine in the blood affected by the FIR energy radiation. The concentration of the adrenaline, noradrenaline and dopamine in the FIR group were significantly lower $14.4 \%$

There are the sympathetic nerves and the parasympathetic nerves in the autonomous nervous system which distribute every internal organ at the same times to control the function of each internal organ in spite of his mind. When the sympathetic nerves excited, the heart beat violently, the blood pressure increase, the breath become hard and the stress build up in the body. On the contrary, when the parasympathetic nerves excited, the feeling become confortable as at home to become feeling an appetite, sleep and sexual desire. It is thought that the rats and the mice radiate FIR energy become loss of the stress in the cage and lives the active and healthy life. In short, FIR energy radiation may avoid the stress and obesity. 


\subsubsection{The effect of the FIR energy radiation on the biological macromolecules}

The effect of FIR energy radiation on the biological macromolecules is being made clear. The effects of FIR energy radiation on the activity of the enzyme can be estimated by using the FIR incubator developed by us. An enzyme is the special protein which has the various amino acids forming the three-dimensional structure with the various bonds to get a special role to a chemical reaction. In case that the activities of the 19 kinds of the enzymes appear in radiating FIR energy, it was made clear that the activity of some enzymes were accelerated or restrained. These results suggested that the efficiency of the enzyme activity changed because the various bond conforming the three-dimensional structure of the enzyme was affected by the FIR energy. In the enzymes measured by us, the results suggested that the activities of esterase, esterase lipase, lipase, leucin allylamidase, betaglucuronidase were accelerated and that of alkaline-phosphatase, acid-phosphatase, naphtol-AS-BI-phospho hydrase were restrained. Especially, esterase, esterase lipase and lipase are the enzymes to decompose a fat. Though the experiments were preliminary study, it was made clear that the FIR energy radiation changed the three-dimensional structure of the various enzymes to accelerate or restrain the activities. Still more, it was possible from the results that the increase of body weight restrained because some decomposition enzyme of fat were restrained by FIR energy radiation. These results suggested that the FIR energy radiation has a diet effect.

\section{Effect of FIR on Lipase}

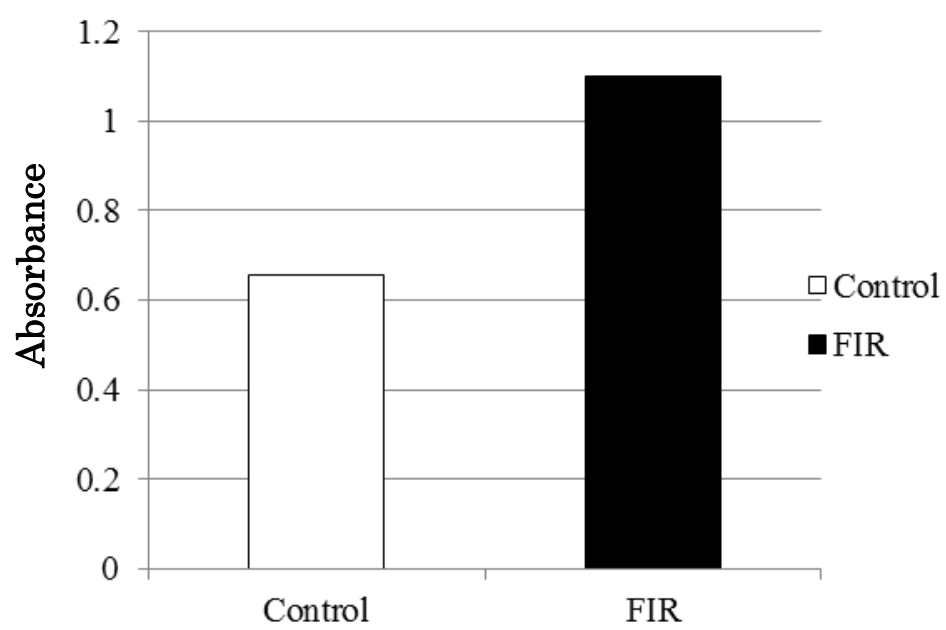

Figure 17. The change of activity of lipase by FIR energy radiation. The activity in the FIR radiation group was higher $40.5 \%$ than the control group at $530 \mathrm{~nm}$. 


\subsection{The effects of FIR energy radiation skin}

\subsubsection{The effect of FIR energy radiation on skin repair}

The wound of circle with $8 \mathrm{~mm}$ diameter was artificially made at the skin of rats keeping the FIR and the control animal raising apparatus. Then, the area of the wound was measured each several days. And the surface condition was observed. The results showed that though the surface of the wound in the FIR radiation group wet and soft, that of the control group was covered the hard scab (Fig.18).
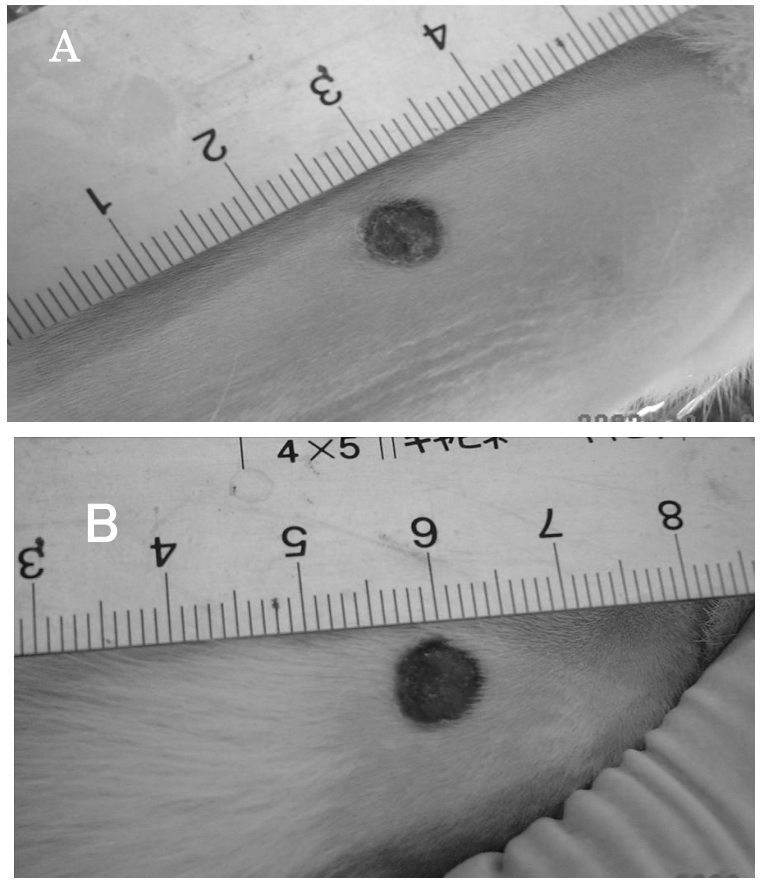

Figure 18. The surface of wound of skin affected by the FIR energy radiation. Control : (A) FIR energy radiation : (B)

The repair area of FIR radiation group increased each $30.54 \%, 28.27 \%$ and $14.22 \%$ after 5, 6 and 7days compared with control group (Fig.19). These results showed that the FIR energy radiation from out of body accelerated the wound healing at the surface of rat skin. Still more, the repair area of wound increased each $44.39 \%$ and $24.29 \%$ after 3 and 5 days by application of the ointment containing the $10 \%$ rhyolite as the FIR energy radiating ceramics. In other words, it was clarified that the FIR energy radiation promoted the wound hearing of skin, even if the radiation of FIR energy were by far from body or by contact with skin. If the blanket and sheet with FIR energy radiation effects were developed, the bedsore of the bedridden old persons or the sick persons in bed for a long time would be suppressed and restored to regenerate the skin and ease the pain of the patients. Now, though the rise in 
a fee for medical treatment becomes a social problem, if the bedsore could be suppressed to shorten the term of the admission to a hospital, the fee for the medical treatment would be reduced in the future. Still more, if the space of the residence was constructed with the FIR energy radiating building material as the rhyolite, the metabolism of skin would be promoted to hinder the aging of skin. Then, the FIR energy radiating ceramics as rhyolite may be tied together with a development of the creams and cosmetics to hinder the aging of skin.

\section{Control}

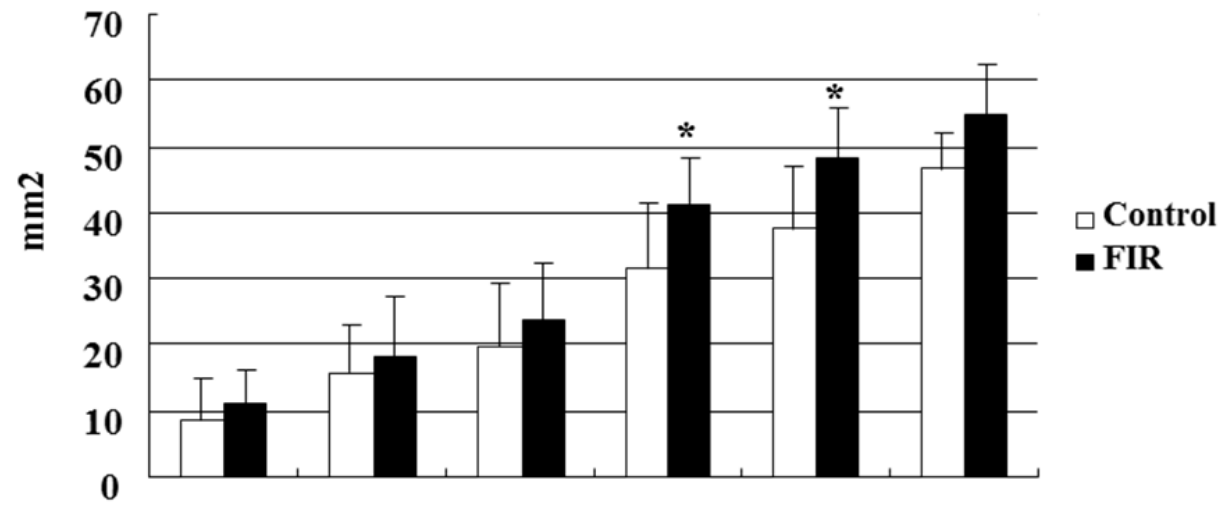

day

Figure 19. The repair area of wound hearing. The speed of repair was accelerated affected by the FIR energy radiation.

\subsubsection{Effect of the FIR energy radiation on a atopic dermatitis}

The mouse naturally induced a crisis of the inflammation of the skin as the atopic dermatitis with the application of a picric acid as the material raising the inflammation was imported from the United States. Then, the effects of the FIR energy radiation on the induction of the inflammation of the skin were analyzed by using the mouse. No an inflammation of skin in the mouse radiated FIR energy was detected after the application of a picric acid, though the atopic dermatitis of control mouse in the same condition were all induced without the FIR energy radiation (Fig.20). It was made clear that the area of the inflammation of skin and the number of the mast cells at the inflammation of skin as an atopic dermatitis clearly decreased by the FIR energy radiation (Fig.21).

These results suggested that the FIR energy radiation was effective for the prevention and the medical treatment to the inflammation of the skin as an atopic dermatitis. In the future, it is thought that the FIR ceramics as the rhyolite are tied together with the development of the medicine or the cure for the inflammation of the skin as an atopic dermatitis. 

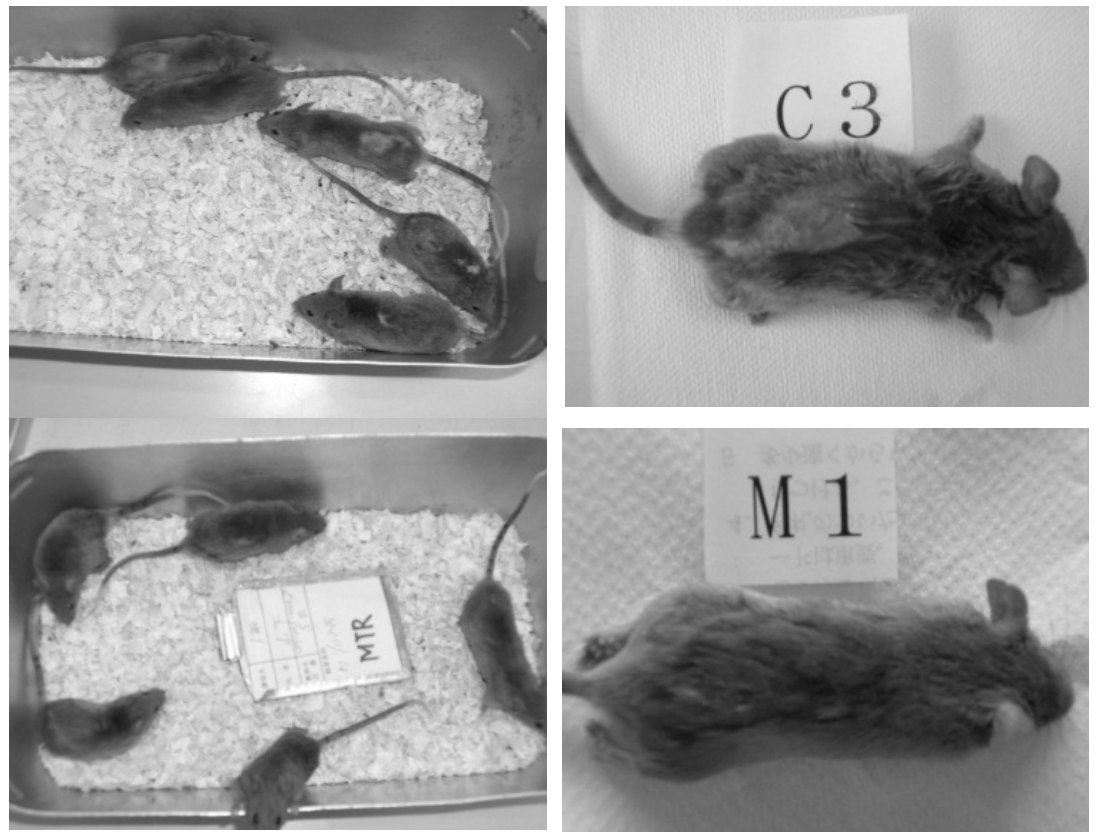

Figure 20. The change of the inflammation of the skin as the atopic dermatitis. The induction of the inflammation of the skin on all mice was suppressed by the FIR energy radiation
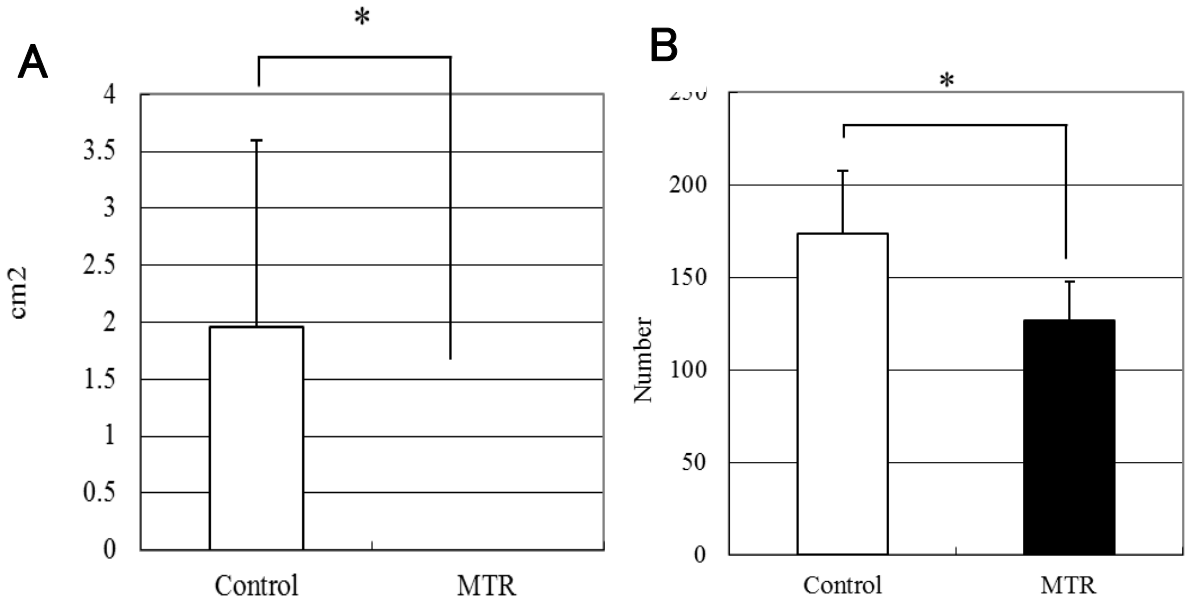

Figure 21. The area of the inflammation of skin and the number of the mast cells at the inflammation. Though the area of the inflammation in control group was $1.96 \mathrm{~cm}^{2}$, no inflammation was detected in the FIR energy radiation group (A). The number of must cells was smaller $26.9 \%$ in the FIR energy radiation group than the control group (B). 


\subsection{The effects of the FIR energy radiation on bone}

\subsubsection{The effect of the FIR energy radiation on the cultured osteoblast-like cells}

The culturing osteoblast-like MC3T3-E1 cell (Riken Cell Banc, Tsukuba, Japan) were separated in the two groups in the FIR and the control $\mathrm{CO}_{2}$ incubator. After 1, 3, 5, 7, 10 and 14days, the cell number of living cells in both groups were measured by a hematocytometer and observed by phase contrast microscope CK40 (Olympus, Tokyo, Japan). Still more, the gene expression of the 4 days culture cells in both groups was analyzed by the cluster analysis the microarray hybridization method (http://www.godatabase.org).

The proliferation of the osteoblast-like MC3T3-E1 cells in FIR group significantly inhibited each $19.08 \%$ and $12.24 \%$ after 3 day and 10days culture compared with control group. But, it was considered that the formation of the calcified nodules in the FIR group was more than the control group by the observation of the culture cells stained with von kossa and with a phase-contrast microscope (Fig.22).
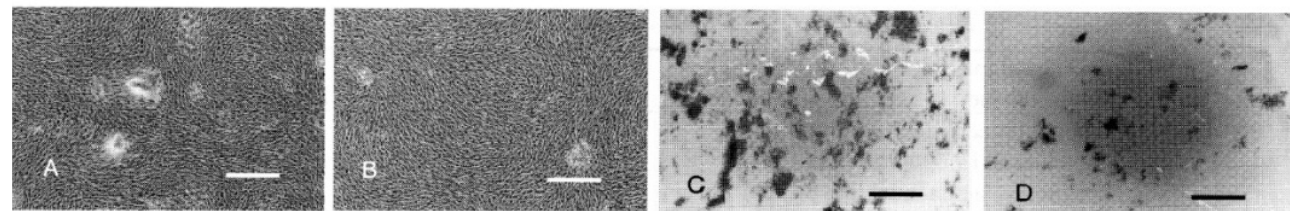

Figure 22. The effects of the FIR energy radiation on the bone nodules formed by MC3T3-E1 cells. The cultured MC3T3-E1 cells in FIR group (A) and control group (B) was observed by the phase contrast microscope CK40 (Olympus, Tokyo, Japan). Some samples after 4weeks culture were stained with Von Kossa method and observed by the same method. FIR group (C) Control group (D) Bar: $100 \mu \mathrm{m}$

The results showed that the number and the area of the calcified nodules of the FIR group were 148.8 and $158.8 \mu \mathrm{m}^{2}$, though no calcified nodules was formed yet in control group after 2 weeks culture. Still more, that of FIR group increased each 2.92times and 4.91times compared with the control group after 4weeks (Fig.23). Consequently, the formation of the calcified nodules was clearly promoted by the FIR energy radiation. On the other hand, it was made clear by the results of cluster analysis after 4 day culture that the genes expression of Interferon activated gene 205, 203 and Interferon $\alpha$-inducible protein 27 in the cell to cell signal field were reinforced and the gene expression of Interleukin 1 family member 6, Interleukin 17D, 17 receptor C, 17B, and Interleukin 3 related with inflammation were oppositely dropped (Table 2).

It was also made clear that the genes expression of Platelet-derived growth factor (PDGF) D polypeptide, Transforming growth factor $\beta$ (TGF $\beta$ ) induced and TGF $\beta$ inducible early growth response 1 in the cell proliferation field were reinforced, and the gene expression of PDGF B polypeptide and Fibroblast growth factor (FGF) 2, 21, 8 were oppositely dropped (Table 2). It was clarified by these data that the cell differentiation as the function of osteoblast estimated by the formation of calcified nodules were promoted by FIR energy 
radiation, though the proliferation was inhibited by it. In short, the FIR energy radiation shorts the term of cell proliferation and advances the timing of cell differentiation on the osteoblast. Finally, it was considered that the FIR energy radiation control these genes expression to inhibit the cell proliferation and promote the cell differentiation of osteoblast $[8,9]$. It was made clear by these facts that the differentiation of cultured osteoblast-like cell as an osteoblast is promoted by the radiation of FIR energy.

\begin{tabular}{|c|c|c|}
\hline $\begin{array}{l}\text { Cell-cell signaling } \\
\text { Gene Name }\end{array}$ & Acc. No. & Fold change \\
\hline $\begin{array}{l}\text { Interferon activated gene } 205 \\
\text { Interleukin } 15 \text { receptor, alpha chain } \\
\text { Interferon alpha-inducible protein } 27 \\
\text { Mitogen activated protein } 3 K 7 \\
\text { Interferon activated gene } 203\end{array}$ & $\begin{array}{l}\text { NM_172648 } \\
\text { NM_008358 } \\
\text { AK010014 } \\
\text { BC006665 } \\
\text { NM_008328 }\end{array}$ & $\begin{array}{l}1.597 \\
1.422 \\
1.388 \\
1.365 \\
1.328\end{array}$ \\
\hline $\begin{array}{l}\text { Interleukin } 1 \text { family, member } 6 \\
\text { Interleukin } 17 \mathrm{D} \\
\text { Heparin-binding EGF-like growth factor } \\
\text { Interleukin } 3 \\
\text { Interleukin } 17 \text { receptor } \\
\text { Interleukin } 17 \mathrm{~B}\end{array}$ & $\begin{array}{l}\text { NM_019450 } \\
\text { NM_145837 } \\
\text { NM_010415 } \\
\text { NM_010556 } \\
\text { NM_134159 } \\
\text { NM_019508 }\end{array}$ & $\begin{array}{l}-1.348 \\
-1.393 \\
-1.395 \\
-1.471 \\
-1.481 \\
-1.631\end{array}$ \\
\hline $\begin{array}{l}\text { Growth } \\
\text { Gene Name }\end{array}$ & Acc. No. & Fold change \\
\hline $\begin{array}{l}\text { Platelet-derived growth factor, D polypeptide } \\
\text { Transforming growth factor, beta induced } \\
\text { TGFb Inducible early growth response } 1 \\
\text { Mitogen activated protein kinase kinase kinase } 7 \\
\text { Growth differentiation factor } 15\end{array}$ & $\begin{array}{l}\text { AK003359 } \\
\text { NM_009369 } \\
\text { NM_013692 } \\
\text { BC006665 } \\
\text { NM_011819 }\end{array}$ & $\begin{array}{l}1.555 \\
1.505 \\
1.383 \\
1.365 \\
1.322\end{array}$ \\
\hline $\begin{array}{l}\text { Fibroblast growth factor } 8 \\
\text { Fibroblast growth factor } 21 \\
\text { Epidermal growth factor receptor related gene } \\
\text { Fibroblast growth factor } 2 \\
\text { Heparin-binding EGF-like growth factor } \\
\text { Early growth response } 3 \\
\text { Growth factor receptor binding protein2-ap } \\
\text { 1(Gab1) } \\
\text { Platelet-derived growth factor, B polypeptide }\end{array}$ & $\begin{array}{l}\text { D12483 } \\
\text { NM_020013 } \\
\text { M99623 } \\
\text { NM_008006 } \\
\text { NM_010415 } \\
\text { NM_018781 } \\
\text { NM_021356 } \\
\text { NM_011057 }\end{array}$ & $\begin{array}{l}-1.323 \\
-1.332 \\
-1.337 \\
-1.342 \\
-1.395 \\
-1.565 \\
-1.667 \\
-2.304\end{array}$ \\
\hline
\end{tabular}

Table 2. The cluster analysis of the gene expression in MC3T3-E1 cells affected by FIR energy radiation by the microarray hybridigestion method These genes were reinforced and repressed at 1.3 over by the FIR energy radiation in the cluster of the Cell-to signaling and the growth. 


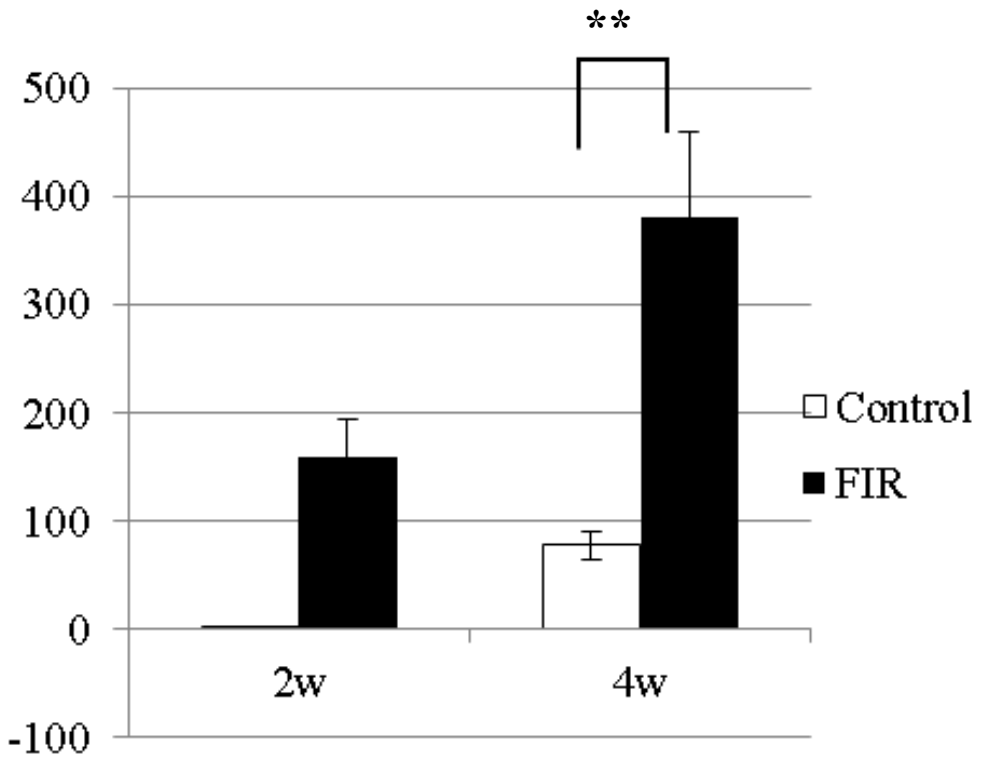

Figure 23. The effects of the FIR energy radiation on the number and the area of the bone nodules formed by MC3T3-E1 cells. Each five samples stained with Von Kossa method after 1, 2, 3 and 4 weeks in both groups were measured the nodules (A) and the number of the area (B) by Bio-system microscope BX-51. The measurement was analyzed by the average of five field of visions of each samples. Statistical analysis was carried out by $\mathrm{t}$-test. ${ }^{*} \mathrm{P}<0.01$

\subsubsection{The effects of FIR energy radiation on the titanium implant}

Pure titanium post (RTP post titanium \#Ti, Dentech, Tokyo) were treated with the snowtech O solution (Nissan Chemical Industries, Tokyo) for 48 hours and immersed in MEM medium (Minimum Essential Medium Eagle, Sigma, St. Louis, MO, USA) for 5 days. Control group was only immersed in MEM medium at same condition. The 20 S.D. rats of 6 weeks old were implanted the titanium post into the central position of the femur. Left side was control group and Right side was the snowtech $\mathrm{O}$ solution treated group. These rats were separated two groups which the FIR energy radiating group kept in the FIR animal raising apparatus and the control group was kept in the normal animal raising apparatus. The femur with the titanium post was extracted and measured the intensity between the titanium and the bone by the tension test with the small omnipotent testing machine (Autograph, Shimadzu, Kyoto) after 1, 2 and 4 weeks raising. The same experiments were repeated twice. Though the data were easy affected by the damage of the surgical operation and the extent of the inflammation, the identical tendency was shown. The tension intensity of the implanted titanium post with the snowtech $\mathrm{O}$ solution in the FIR energy radiating group significantly reinforced 2.68 times as much as the same implant in the control group after 2 weeks (Fig.24). 


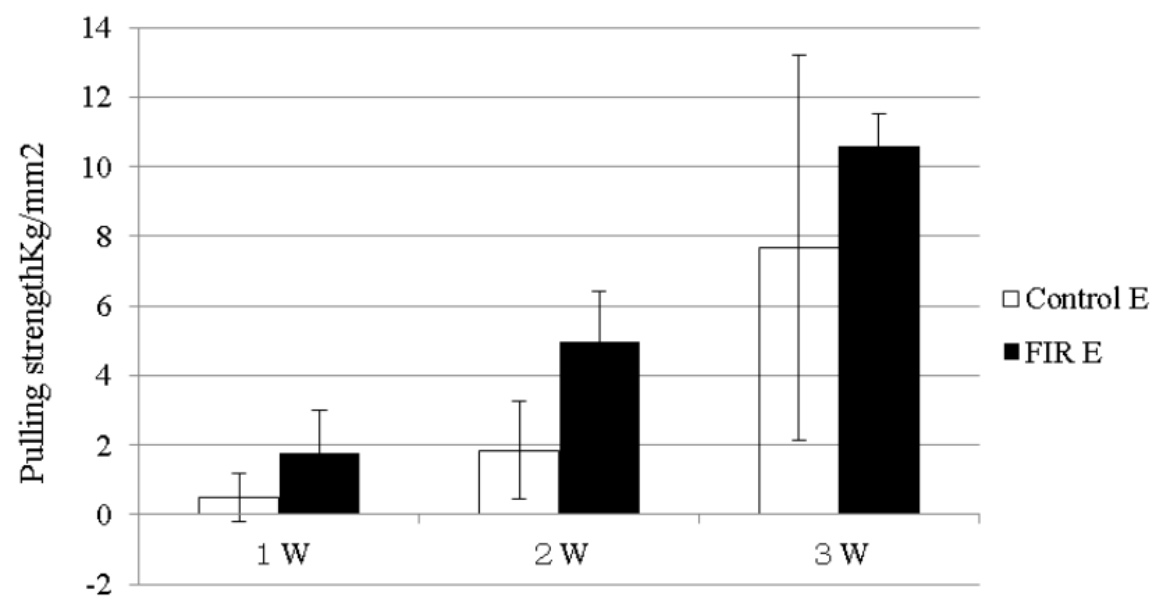

Figure 24. The effect of the FIR radiation on the strength of the bone bonding to titanium. The bone bonding to titanium was clearly promoted by the FIR energy radiation.

It was been thinking that FIR energy was too weak to permeate deep into the tissue of the living body. But, if the FIR energy radiation affects the water molecules in the blood as mentioned previously, the blood of the whole body was affected by FIR energy even if the deep position. The possibility is supported by the experimental results which the new bone formation inside of the femur was activated by the FIR energy radiation at the surface of the skin from outside of body.

It is suggested that the deformational vibration of the water molecules in the blood affected by the FIR energy radiation was activated by the transmission of the energy through the resonance effect because the energy of deformation vibration was coincident with the radiating energy. It was proved that the blood containing the activated water molecules become quickly flow into the bone to activate the new bone formation.

\subsubsection{The effects of the feed containing the FIR ceramics on the growth of bone}

The powder of the rhyolite mined at the vein of ore located on the Median Tectonic Line around Ehime prefecture was utilized for this experiment. The composition of the ingredient is $\mathrm{SiO} 266.8 \%$, $\mathrm{Al} 2 \mathrm{O} 3$ 13.52\%, Fe2O3 6.98\%, $\mathrm{K} 2 \mathrm{O} 4.19 \%, \mathrm{Na} 2 \mathrm{O} 3.98 \%$, $\mathrm{CaO} 2.55 \%$. The 60 rats of SD strain at 4 weeks old were separated the three groups of $0.01 \%$ and $0.1 \%$ FIR treated and control. The each group was raised every 2 or 3 days with the standard feed containing $0.01 \%$ and $0.1 \%$ rhyolite and nothing for the each group in the measurement the amount of the eating feed. After 115days, all rats were killed by the over anesthesia and the femur and the tibia were measured at many parts of width and the length.

By the results of experiments, the amount of the eating feed of $0.01 \%$ FIR treated group increased up to $6.3 \%$, that of $0.1 \%$ FIR treated group decreased on the contrary compared with the control group. The width of the right femur at distal, central and postal position significantly grew each $3.2 \%, 21.4 \%$ and $12.3 \%$ and that of the right tibia at central position 
and the left femur at the distal position grew $1.3 \%$ also. The width of the right femur at central and distal position significantly grew each $3.7 \%$ and $6.1 \%$, and that of the right tibia at central position and the left tibia at the distal position grew $11.8 \%$ also. Then, on the length of the long bone, the left tibia significantly grew $2.4 \%$ alone. The special affected parts were shown at Fig.25. It was clarified that the width of the femur and tibia quickly grew as shown in Fig.25.

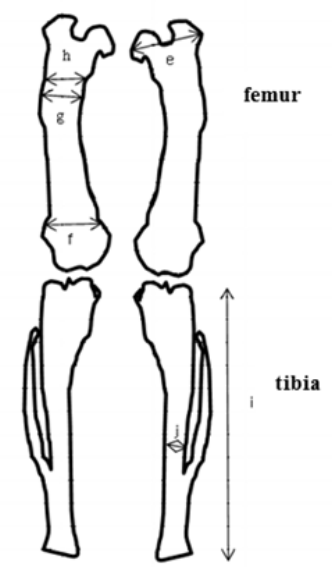

A

Right Left
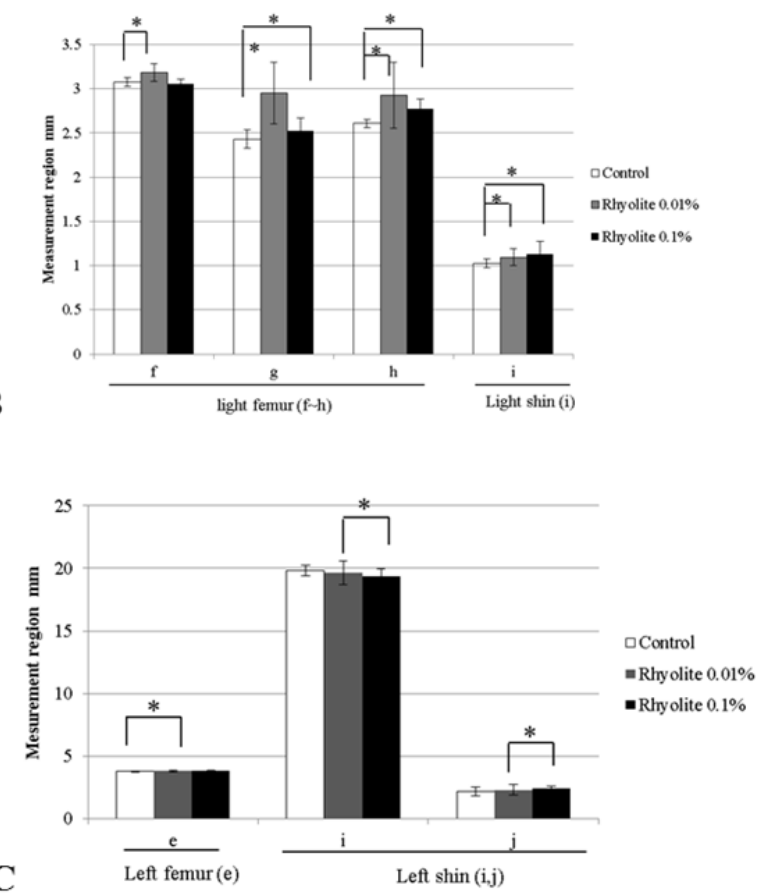

Figure 25. The effect of the eating the feed containing rhyolite on the growth of the bone. The measurement parts of the femur and the tibia were shown (A). The growth of the femur and the tibia of these three groups of $0.01 \%$ and $0.1 \%$ FIR treated and control were compared after 115 days. Right : (B), Left : (C) It was clarified that the width of the femur and tibia quickly grew in the $0.01 \%$ FIR group.

It was made clear by these results that the bone formation was promoted by the inside radiation from the digestive organs by eating the feed containing the FIR energy radiating ceramics as same as the outside radiation of the FIR energy. These results suggest that the FIR energy radiation from the digestive organs arrives easy the deep posited bone of the living body. Still more, it was thought that the growth of length was a little inhibited and that of width was promoted. In other words, the FIR energy radiation does not promote the intrachondral ossification but the intra-membranous ossification that the osteoblast directly differentiates from the undifferentiated cells. As the effects of the bone affected more sensitive than the cartilage with the blood capillary, it was thought that the bone formation by the osteoblast is promoted by the FIR energy radiation. The results also prove that the 
FIR energy radiation affected the living body though the blood containing many water molecules. It was clarified that the FIR energy radiation promotes the bone formation though the energy transmission to water molecules.

\subsection{The Effects of the FIR energy radiation on the cancer}

\subsubsection{The Effects of the FIR energy radiation on the culture cancer cells}

In order to clarify the effects of the FIR energy radiation on the culture cancer cells, A431 human epithelial vulva carcinoma cells, Sa3 human gingival squamous carcinoma cells, HSC3 human tongue squamous carcinoma cells, A549 human lung carcinoma cells, and MCF7 human breast carcinoma cells were cultured for the analysis of the effects on the proliferation, the shape of cells and the induction of apoptosis.

A431, A549, and MCF7 cells were cultured in Dulbecco's modified Eagle's medium/Ham's F-12 nutrient mixture (Sigma, St. Louis, MO, USA). HSC3 and Sa3 cells were cultured in Eagle's basal medium (Sigma). All culture medium was supplemented with $10 \%$ heatinactivated fetal bovine serum. The cells $\left(5 \times 10^{4}\right)$ were plated and measured on days 8 using $0.2 \%$ trypan blue and the hemocytometer. Incorporation of 5-bromo-2'-deoxyuridine (BrdU) was used to determine the amount of DNA synthesis. Cells were observed with a CK40 phase contrast microscope (Olympus, Tokyo, Japan), fixed, and stained with hematoxylin and eosin. Still more, apoptotic cells were identified using an Apo-BrdU in situ DNA Fragmentation Assay Kit (Bio Vision, Mountain View, CA, USA).

Although the proliferation of A549, HSC3, and Sa3 cells was significantly suppressed from day 6 of culture $(59.0 \%, 75.4 \%$, and $76.2 \%$, respectively) up to at least day 10, FIR irradiation had little effect on the growth of A431 or MCF7 cells. Measurement of BrdU incorporation on day 4 of culture also showed a significant suppression of growth by FIR irradiation in A549, HSC3, and Sa3 cells but not in A431 or MCF7 cells. Observation of the morphology by the phase contrast microscopy revealed that the cytoplasm and nucleus was enlarged in A549 cells. Some of the HSC3 cells also showed hypertrophy of the cytoplasm and nucleus and others tended to show atrophy. Finally, some of the Sa3 cells showed hypertrophy of the cytoplasm (to refer JEMAA 2010, 2, 382-394, Fig.1) [10]

To determine whether the inhibition of proliferation by FIR energy radiation was associated with apoptosis or necrosis, cancer cells were subjected to FIR irradiation of $48 \mathrm{~h}$ and analyzed on day 4 by staining with annexin V-FITC and PI and by TUNEL (TdT-mediated dUTP-biotin nick end labeling) (to refer JEMAA, 2010, 2, 382-394, Fig.3)[10]. These results indicated that FIR did not induce apoptosis in A431, HSC3, or Sa3 cells. A few of the Sa3 cells showed significant necrosis. These results indicate that the inhibition of proliferation by FIR in the cancer cells, particularly in HSC3 and Sa3 cells, was not due to apoptosis. Still more, in order to analyze all expressing genes induced by FIR energy radiation, the control and the FIR-irradiated samples after four days culture was monitored using a Qiagen RNeasy Mini Kit (Qiagen, Valencia, CA, USA) with elimination of low signal feature of background signal $+2.6 \times \mathrm{SD}$, and $\mathrm{P}$ value $<0.01$. Genes were further classified for process and function according to their 
A431

\begin{tabular}{|c|c|c|}
\hline Genkank & Desciption & Fold change \\
\hline NM_014316 & Calcium regulated heat stable protein $1,24 \mathrm{kDa}$ & 1.777 \\
\hline AJ131186 & PRP19/PSO4 pre-mRNAprocessing factor 19 homolog & 1.754 \\
\hline NM_007056 & Splicing factor, agininineserine-rich 16 & 1.706 \\
\hline NM_003824 & Fas(TNFRSF6)-associated via death domin & 1.518 \\
\hline NM_130469 & Jun dimerization protein 2 & 1.493 \\
\hline NM_ 031209 & quaine RNA-tibosyttransferase 1(tRNA-guaninetangolycosylase) & 1.491 \\
\hline NM_003564 & trangelin2 & 1.482 \\
\hline NM_021826 & FAST kinasedomains S(FASTKDS) & 1.480 \\
\hline Вт007321 & gencral transcription factur IIH, podypeptide $4,52 \mathrm{kDa}$ & 1.383 \\
\hline AF099011 & EH-domin containing 1 & 1.382 \\
\hline NM_153361 & Hypothetical protein MGC42105 & -4.525 \\
\hline NM_009589 & arylsulfatase D & 4.016 \\
\hline NM_000125 & estrogen receptor 1 & -3.891 \\
\hline NM_032726 & phospholipase C, detta 4 & -3.745 \\
\hline NM_066477 & RAS-relatad on chromosome 22 & -3.472 \\
\hline NM_004797 & Adiponetin, $\mathrm{ClQ}$ and collagon domain oontaining & -2513 \\
\hline NM_015555 & zinc finger proxein 451 & -2506 \\
\hline NM_00285 & AF4/FMR2 fanily, member 3 & -2469 \\
\hline NM_012410 & Seizrerelated 6 homolog(mouse)-Hike 2 & -2463 \\
\hline NM 005242 & Coagulation factor IIf(trombin) receptor-kke 1 & -2066 \\
\hline
\end{tabular}

\begin{tabular}{|c|c|c|}
\hline Gankank & Description & Fold change \\
\hline NM_006743 & RNAbindingmodif(RNPI,RRM)protein 3 & 3.046 \\
\hline NM_014563 & trafficking protein particle complex 2 & 1.964 \\
\hline NM_014316 & calcium regulated heat stable protein $1,24 \mathrm{k} \mathrm{Da}$ & 1.945 \\
\hline NM_001280 & cold inducible RNA binding protein & 1.825 \\
\hline NM_000475 & mudear receptar subfamily 0 ,group $B$, member 1 & 1.805 \\
\hline NM_145307 & plockstrin homology domain containing, family $K$ member 1 & 1.788 \\
\hline NM_013962 & neuregulin 1 & 1.731 \\
\hline NM_182687 & protein kinase, membrane associated tyssinethreocnine 1 & 1.725 \\
\hline NM_ 024680 & $\mathrm{E} 2 \mathrm{~F}$ transcription factor 8 & 1.710 \\
\hline NM_006123 & iduronate 2-sulfatase(Hunter sydrome) & 1.688 \\
\hline NM_000508 & fitrinogen alpha chain & -3.571 \\
\hline NM_005039 & prolinerich protein B\&NN subfamily 1 & -3.185 \\
\hline NM_002113 & complement factor $\mathrm{H}$-rclatad l & .2899 \\
\hline NM_001885 & crystalline, apha B & -2801 \\
\hline NM_001964 & eary growth response 1 & -2.513 \\
\hline NM_004617 & transmambrance $4 \mathrm{~L}$ six familymanbor 4 & -2.463 \\
\hline NM_006744 & retind binding protein 4, plasma & -2410 \\
\hline NM_004543 & nekxlin & -2.353 \\
\hline NM_000204 & Ifactor(complementit) & -2.331 \\
\hline NM_ 021870 & Fitrinogen gamma chain & -2288 \\
\hline
\end{tabular}

\begin{tabular}{|c|c|c|}
\hline Gentinis & Dequitin & Fistangr \\
\hline NM_O144II & Nasopharyngeal carconoma assocuated gene proten-8 & 4.253 \\
\hline NM_032972 & protocaadhein 11Y-linkod & 4.037 \\
\hline NM_ 005854 & receptor(calcitonin)activity modifying protein 2 & 3.662 \\
\hline NM_001485 & gastrulation brain homeobox 2 & 3570 \\
\hline NM_015831 & actyldholinesterase(YT blood group) & 3.528 \\
\hline NM_03237 & hypothetical protein FL 223356 & 3.478 \\
\hline NM_024867 & KPL2protein & 3.472 \\
\hline NM_004132 & hyahuronan binding protein 2 & 3.345 \\
\hline NM_002602 & phoophodiesterase $6 \mathrm{G}$, oGMP-spocific, rod, ganma & 3.205 \\
\hline NM_178536 & lipocalcin 12 & 3.186 \\
\hline NM_002733 & protén kinase, AMP-activated, gamma Inon-catalytyc subunit & -2.309 \\
\hline NM_ 031266 & heterogeneous mudear ribonucleoprotein $\mathrm{AB}$ & -2.212 \\
\hline NM_005556 & keratin 7 & -2.105 \\
\hline NM_006753 & surfét6 & -1.996 \\
\hline NM_006925 & splicing fiator, argininessame-rich 5 & -1.988 \\
\hline NM_022044 & stromal cell-derived fictor 2 -like 1 & -1.984 \\
\hline NM_005694 & COX17 hamolog, cytochrome coxidase assembly protein(yeast) & -1.828 \\
\hline NM_ 018645 & Hairyand enhancer of split 6 (Drospphila) & -1.821 \\
\hline NM_005954 & matallohionein 3 (growth inhibitioy factor (nearortrophic)) & -1.761 \\
\hline
\end{tabular}

MCF7

\begin{tabular}{|c|c|c|}
\hline Genhank & Descrintion & Fold change \\
\hline NM__006743 & RNAbindingmodif(RNP1,RRM)protein 3 & 2793 \\
\hline NM__12403 & 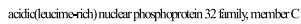 & 2763 \\
\hline NM_-12404 & acidiolencimerich) muclear phosphoproten 32 family, member D & 2583 \\
\hline NM_ 014316 & calcium regulated heat stable protein $1,24 \mathrm{kDa}$ & 2304 \\
\hline $\mathrm{BC} 022779$ & v-akt munine thymoma viral oncogene homolog 2 & 1.846 \\
\hline NM_-001719 & bonemaphogenticic protèn 7(ostoogeniic protein 1) & 1.817 \\
\hline NM_ 017590 & zinc fingre $\mathrm{COCH}$-type containing $7 \mathrm{~B}$ & 1.736 \\
\hline NM_ 052960 & retind binding protein 7 , cellular & 1.598 \\
\hline NM_005724 & tetraspanin 3 & 1.577 \\
\hline NM_ 032129 & pleckstrin homdogy domain conlaining, fammily Nmember 1 & 1.479 \\
\hline NM__20317 & chromosme 1 cpen reading frame 63 & -1.938 \\
\hline NM_-005803 & floillilin 1 & -1.835 \\
\hline NM_001967 & eukaryotic translation initiation factor $4 \mathrm{~A}$, isoform 2 & -1.779 \\
\hline NM__005345 & heat shock 70kDaprotein $1 \mathrm{~A}$ & -1.748 \\
\hline NM_ 015528 & ring finger protein 167 & -1.698 \\
\hline NM_ 032272 & MAFl homolog(S. arevisiac) & -1.675 \\
\hline NM_ 024786 & zinc finger, DHHC-ype containing 11 & -1.667 \\
\hline NM_ 005275 & granine nuclootide binding protein-like 1 & -1.650 \\
\hline NM_003516 & histone2, H2aa & -1.645 \\
\hline NM 001964 & early growthresponse 1 & -1.623 \\
\hline
\end{tabular}

Sa3

\begin{tabular}{|c|c|c|}
\hline Genkank & Description & Fold change \\
\hline NM_006121 & kcratin((piddmalytichyparkcratoris) & 2.383 \\
\hline NM_014316 & calcium regulated heat stable protein $1,24 \mathrm{kDa}$ & 1.934 \\
\hline NM_001946 & dual specificityphosphatase 6 & 1.805 \\
\hline NM_005547 & involucin & 1.756 \\
\hline BC006322 & activating transcription factor 3 & 1.753 \\
\hline NM_005555 & kcratin $6 \mathrm{~B}$ & 1.750 \\
\hline NM_003125 & small proline-rich proveien 1B(cornifin) & 1.656 \\
\hline NM_ 014604 & Tax(human T-oell lakkemia vinus type I) binding pootein 3 & 1.605 \\
\hline NM_003315 & Draal(Hsp40hamolog sublamily C, member 7 & 1.568 \\
\hline NM_002964 & S100 calcium binding protein $\mathrm{A} \&($ calgramulin $\mathrm{A})$ & 1.564 \\
\hline NM_ 005359 & SNAD, mothers against DDPhomolog 4(Drosophila) & -1.976 \\
\hline NM_001348 & death-associated protein kinase 3 & -1.698 \\
\hline NM_130901 & OTUdomain containing 7 & -1.695 \\
\hline NM_000524 & 5-hydroxyty ptamine(serotonin)receptor $1 \mathrm{~A}$ & -1.667 \\
\hline NM_-066419 & chemokine(CX-Cmodif) ligand 13 (B-cell chemoattractant) & -1.667 \\
\hline NM_032805 & zinc finger protein 206 & -1.623 \\
\hline NM_207370 & G proxtein-coupled receptor 153 & -1.618 \\
\hline NM_020999 & ncurogunin 3 & -1.595 \\
\hline NM_005205 & cytochrome coxidase subunit Va polypeptide 2 & -1.592 \\
\hline NM_-004118 & forkhend-like 18(Drososphila) & -1.590 \\
\hline
\end{tabular}

Table 3. The analysis of the extracted genes induced by the FIR energy radiation. The 10 most promoted genes and the 10 most inhibited genes in these changed genes showed 
By the results that the significant changed genes of the 5 cancer cells by the FIR energy radiation were search, the cells inhibited the proliferation and showed that the many genes related the proliferation changed. The number of the inhibited genes by FIR energy radiation is more than that of the promoted gene except for the HSC3 cells. The 10 most promoted genes and the 10 most inhibited genes in these changed genes were shown at Table 3 . There is no common gene in the expressed gene of 5 cells. These genes contained mainly the transcriptional factor and the control factor of the transcriptional factor.

\subsubsection{The control system in the cancer cells for the FIR energy radiation}

At the process of the analysis of the gene expression induced by the FIR energy radiation, it was made clear that the gene expression of HSP (Heat Shock Protein) 70 was reinforced by the FIR energy radiation. Therefore, the hyper expression cells and the knockdown cells of HSP70 were formed to analyze the effect on the proliferation.

In order to directly determine whether HSP70 can protect cells from FIR-induced cell death, we developed A431 and HSC3 cell lines stably expressing human HSP70A (A431-HSP70A and HSC3-HSP70A cells, respectively). Control cells were transfected with empty pcDNA3.1 (A431-Neo and HSC3-Neo). In our initial experiments, we found that the exposure of HSC3 and Sa3 cells but not A431 cells to the FIR energy radiation causes $\mathrm{G} 2 / \mathrm{M}$ arrest and induces partial hypertrophy to the necrosis (data not shown) [12]. To determine whether the increased expression of HSP70A confers protection against the FIR energy radiation, the cell survival was examined in FIR-irradiated A431-HSP70, A431Neo, A431-wt, and HSC3-HSP70, HSC3-Neo, and HSC3-wt cells. We found that over expression of HSP70A increased the cell proliferation in A431 and HSC3 cells. Furthermore, the proliferation of FIR-irradiated and control (unirradiated) A431-HSP70A cells was similar. The survival rate after 6 days of FIR irradiation was significantly higher in HSC3-HSP70A cells than in HSC3-Neo or HSC3-wt cells. In addition, the proliferation of FIR-treated HSC3-HSP70A cells was similar to that of control HSC3-HSP70A cells. The BrdU incorporation was significantly higher in FIR-irradiated or control A431-HSP70A cells than in A431-Neo or A431-wt cells. Although the BrdU incorporation of FIRirradiated HSC3-wt and HSC3-Neo cells was lower than in unirradiated HSC3-wt and HSC3-Neo cells, it was similar in FIR-irradiated and unirradiated HSC3-HSP70A cells (to refer Med.Oncol 2008, 25, 229-237, Fig.3)[9].

HSP70 appears to be present in a variety of normal cell types and its expression may be induced by several stressors, such as hyperthermia, cardiac ischemia, infection, UV radiation, endotoxin, and nitric oxide to suppress or denature any foreign protein and restore an injured protein from lethal effects [13]. HSP70 seems particularly important for cancer cells. In human breast cancer, the expression of HSP70 correlates with increased cell proliferation, poor differentiation, lymph node metastases, and poor therapeutic outcome [14]. In vivo animal studies and clinical trials have revealed that hyperthermia may serve as a powerful tool in the treatment of prostate cancer [15-20]; at the cellular level, hyperthermic 
stress induces HSPs. Moreover, chemotherapeutic agents such as cisplatin, adriamycin, and bleomycin, as well as $\gamma$-radiation induce HSPs. HSP70 participates in cytoprotection and is associated with cellular resistance to lethal external effects [18-21]. However, in the present study, HSP70 was never induced by FIR. These results suggested that FIR has anti-tumor activity without inducing HSP70 as an anti-stress factor. This characteristic indicates that FIR may be suitable for medical treatment.

We next examined the effect of knocking down HSP70A and HSP70C mRNA and HSP70 protein expression using siRNA. Transfection with HSP70A/C siRNA effectively decreased HSP70A and HSP70C mRNA (Fig. 4A) and protein levels in both A431 and HSC3 cells without affecting the level of HSP70B mRNA or protein. HSP70A/C siRNA did not suppress BrdU incorporation in unirradiated A431 cells, but it suppressed BrdU incorporation in cells irradiated with FIR. Similarly, the HSP70A/C siRNA enhanced the suppression of BrdU incorporation by FIR irradiation. FIR irradiation also significantly suppressed BrdU incorporation in HSC3 cells transfected with the negative control siRNA. These results indicate that a decrease in HSP70 protein mediates the ability of limited FIR to inhibit the proliferation of A431 and HSC3 cells (to refer Med.Oncol 2008, 25, 229-237, Fig.4)[9].

\subsubsection{The effects of the FIR energy radiation on the implanted cancer cell to mice}

For experiments on body weight change, 10-week-old male skid mice (CB17/Icr-Prkdc) and 6- to 8-week-old male nude mice (Crlj:CD1-Foxn1) purchased from Charles River Japan (Yokohama, Japan) were housed with temperature control and a 12-h light-dark cycle. Male skid mice were weighed every 5 days, beginning at 10 weeks of age. FIR treatment by our developed animal raiser (FIR group), $n=7$ and control (control group), $\mathrm{n}=8$.

The log-phase cancer cells cultured in 10\% FBS and DMEM/HamF-12 medium (Sigma, St. Louis, USA) resuspended at a cell density of $1 \times 10^{7} \mathrm{ml}$ in PBS containing $500 \mu \mathrm{g} / \mathrm{ml}$ of MatrigelTM basement membrane matrix (Becton Dickinson Labware, Two Oak Park, Bedford, MA). The tumor cells $\left(1 \times 10^{6}\right)$ were suspended in $0.1 \mathrm{ml}$ of PBS containing $50 \mu \mathrm{g}$ of MatrigelTM and were slowly hypodermically injected in the back using a 25-gauge needle. After injecting tumor cells, mice were separated two groups: FIR group and control group. During the experiments, the long and short diameters of the resulting tumor were measured in five-day intervals, and tumor volume was calculated by the following formula: tumor volume $(\mathrm{mm} 3)=1 / 2 \times($ long diameter $) \times($ short diameter $) 2$.

For purpose of the ascertaining tumor organization change by the FIR energy radiation, the excised tumor was observed after stained with hematoxylin and eosin to detect tumor organization change after 30 days.

Then we carried out immunohistochemical analyses to detect matrix metalloproteinases (MMP) members MMP-1, MMP-9, MMP-10 and MMP-13 [9]. The increase in tumor volume 
after implantation was significantly suppressed by whole-body FIR starting from day 15, compared to the control group (to refer J Table1). The cDNA microarray analysis of tumor samples of control and FIR-treated showed that MMP-1, MMP-9, MMP-10, and MMP-13 in the MMP family were significantly down-regulated in the FIR group compared with control group (to refer ITEL 2005, 6(6), 597-601, Table1) [9]. The expression profiles obtained from cDNA microarray analyses as analyzed by quantitative real-time RT-PCR showed the control group to have highly significant overexpression of the genes for MMP-1, MMP-9, MMP-10, and MMP-13 compared to the FIR group (to refer ITEL 2005, 6(6), 597-601, Fig.4) [9].

These results suggest that suppression of tumor volume increase by in vivo FIR radiation was due to inhibition of MMPs by FIR radiation. In other words, FIR suppresses invasion and metastasis of tumor cells by inhibiting the expression of MMP-1, 9, 10 and 13.

As shown in (to refer ITEL 2005, 6(6), 597-601, Fig 5) [9], extensive portions of tumor tissue in the FIR group was encapsulated and necrotized in intra tumor division. On the other hand, in the control group tumor cells showed active proliferation and invasion into the surrounding muscular tissue. In addition, evaluation of the immunohistochemical expression of MMP-1, MMP-9, MMP-10 and MMP-13 using tumor tissues of control and FIR groups on day 30 after implantation showed MMP-1 and MMP-9 to be positively expressed in the tumor stroma of the control group, while MMP-10 and MMP-13 were strongly positive in tumor parenchyma (the part positively dyed at Cytokeratin10) (to refer ITEL 2005, 6(6), 597-601, Fig. 6) [9]. However, these MMPs in the FIR group were not significantly expressed. The result of immunohistological detection for these MMPs was concordant with the results of cDNA microarray and QRT-PCR. That is, FIR radiation seemed to suppress invasion of tumor cells by inhibiting the expression of MMP-1, MMP-9, MMP-10, and MMP13.

The increased expression and activity of MMPs is associated with tumor invasion, metastasis, and angiogenesis [22]. The role of MMP-1 in tumor invasion and metastasis has only recently been determined [23]. MMP-1 has been shown to cleave entactin, thus contributing to the degradation of basement membranes and hence potentially contributing to the transitioning across epithelial barriers by tumor cells [24]. Immunohistochemical detection of MMP-1 expression is also associated with increased invasive potential and poor prognosis in colon and esophageal cancers $[25,26]$. The first barrier to tumor invasion is the basement membrane, and because one of its principle constituents is type I collagen, the gelatinases (MMP-2 and MMP-9) are thought to play important roles in its degradation [27]. MMP-10 (stromelysin-2) is known to degrade various components of the extracellular matrix, and though it has been reported that MMP-10 (stromelysin-2) expression by lymphoma cells accelerates the growth of thymic lymphoma [28], the role of MMP-10 in other types of tumor growth is relatively unknown. MMP-13 (collagenase-3) is expressed in breast carcinoma and in articular cartilage of arthritic patients [29]. In addition, MMP-13 has high collagenolytic and gelatinolytic activity, and MMP-13 may be of importance in 
degradative processes involved in breast cancer progression [29]. In the present study, it was suggested that MMP-1, MMP-9, MMP-10, and MMP-13 are important for the invasion and metastasis of epithelial cancer of the human vulva A431 cell line in vivo and that the activities of MMP-1, MMP-9, MMP-10, and MMP-13 are selectively inhibited by FIR irradiation.

In conclusion, FIR irradiation can suppress tumor growth and invasion of epithelial cancer of the human vulva tumor by inhibiting the expression of MMP-1, MMP-9, MMP-10, and MMP-13 without critical side effects. Inhibition of MMP expression was considered to be one of the mechanisms by which multiplication of A431 tumor cells was suppressed in FIR irradiation.

\section{Conclusion}

It was made clear that the motion of the water molecules was surely and physically activated by the radiation of FIR with the $\mathrm{CO}_{2}$ incubator and the animal raising apparatus. The analysis of the change of blood circulation conducted the conclusion that the FIR energy radiation activated not only the motion of water molecules but also the blood circulation in the living body. Still more, it was made clear that the activation effects on the water molecules developed the activation effects of the skin regeneration and the new bone formation. Moreover, the proliferation or metastasis of the various cancer cells were inhibited by the FIR energy radiation connected with the activation of blood circulation. It is expected that the present studies on the FIR energy radiation connect with the development of medical treatment for the regeneration of the tissue and organ as a skin and a bone, and the prevention medicine for cancer.

\section{Author details}

Kikuji Yamashita

Department of Oral and Maxillofacial Anatomy, Institute of Health Biosciences,

The University of Tokushima Graduate School, Tokushima, Japan

\section{References}

[1] Inoué S, Kabaya M. Biological activities caused by far-infrared radiation. Int J Biometeorol 1989;33(3) 145-150.

[2] Honda K, Inoué S. Sleep-enhancing effects of far-infrared radiation in rats. Int J Biometeorol 1988;32(2) 92-94.

[3] Udagawa $Y$, Nagasawa H. Effects of far-infrared ray on reproduction, growth, behaviour and some physiological parameters in mice. In Vivo 2000;14(2) 321-326. 
[4] Udagawa Y, Nagasawa H,Kiyokawa S. Inhibition by whole- body hyperthermia with far-infrared rays of the growth of spontaneous mammary tumors in mice. Anticancer Res 1999;19(5B) 4125-4130.

[5] Toyokawa H, Matsui Y, Uhara J, Tsuchiya H, Teshima S, Nakanishi H, Kwon A-H, Azuma Y, Nagaoka T, Ogawa T, Kamiyama Y. Promotive effects of far-infrared ray on full-thickness skin wound healing in rats. Exp Biol Med (Maywood) 2003;228(6) 724729.

[6] Udagawa Y, Inada K, Nagasawa H. Inhibition by Single Whole-Body Hyperthermia with Glucose Administration of the Growth of Spontaneous Mammary Tumors in Mice. Jpn J Hyperthermic Oncol 2000;16(4)229-236.

[7] Nagasawa H, Inada K, Ishigame H, Kusakawa S, Udagawa Y. Different Schedules of Whole-Body Hyperthermia with or without Glucose for the Inhibition of Mammary Tumors and Uterine Adenomyosis in SHN Mice. Bulletin of the School of Agriculture, Meiji University 2001 ; 43-51.

[8] Yamashita K, Hosokawa H, Ishibashi J, Ishikawa N, Morimoto H, Ishikawa T, Nagayama M, Kitamura S. Development of CO2 Incubator with Limited FarInfrared Radiation for Activation of Glucose Metabolism. ITE Letters BNTN 2005; 6(5) 53-57.

[9] Hosokawa H, Yamashita K, Ishibashi J, Ishikawa N, Morimoto H, Ishikawa T, Kitamura M, Nagayama M. A New Animal Raiser: Effect of Limited Infrared Radiation on Tumor Growth of A431 Cells. ITE Letters BNTM 2005; 6(6) 597-602.

[10] Egawa H, Takada K, Sasaki Y. (Eds) Far infrared ray. Ningentorekishisha Inc Tokyo 1999; 3.

[11] Ishibashi J, Yamashita K, Ishikawa T, Hosokawa H, Sumida K, Nagayama M, Kitamura $\mathrm{S}$. The effects inhibiting the proliferation of cancer cells by far-infrared radiation (FIR) are controlled by the basal expression level of heat shock protein (HSP) 70A. Med Oncol (Northwood, London, England) 2008; 25(2) 229-237.

[12] Yamashita K, Shine-Od Dalkhsuren, Ishikawa T, Sumida K, Ishibashi J, Hosokawa H, Ueno A, Nasu F, Kitamura S. Far-infrared ray radiation inhibits the proliferation of A549, HSC and Sa3 cancer cells through enhancing the expression of ATF3 gene. J Electromag Anal 2010; 4(2) 382-394.

[13] Wong H R, et al. Increased expression of heat shock protein-70 protects A549 cells against hyperoxia. Am J Physiol 1998;275(4 Pt 1) L836-41.

[14] Nylandsted J, Brand K, Jaattela M. Heat shock protein 70 is required for the survival of cancer cells. Ann N Y Acad Sci 2000; 926:122-125.

[15] Kaplan I, Kapp DS, Bagshaw MA. Secondary external-beam radiotherapy and hyperthermia for local recurrence after 125-iodine implantation in adenocarcinoma of the prostate. Int J Radiat Oncol Biol Phys 1991;20(3) 551-554.

[16] Kaver I, Ware JL, Koontz WW Jr.The effect of hyperthermia on human prostatic carcinoma cell lines: evaluation in vitro.Jr J Urol 1989;141(4) 1025-1027. 
[17] Paulus JA, Tucker RD, Flanagan SW, Moseley PL, Loening SA, Park JB. et al. Heat shock protein response in a prostate tumor model to interstitial thermotherapy: implications for clinical treatment. Prostate 1993;23(3) 263-270.

[18] Roigas J, Wallen ES, Loening SA, Moseley PL. Effects of combined treatment of chemotherapeutics and hyperthermia on survival and the regulation of heat shock proteins in Dunning R3327 prostate carcinoma cells. Prostate 1998;34(3) 195202.

[19] Servadio C, Leib Z. Local hyperthermia for prostate cancer. Urology 1991;38(4) 307309.

[20] Yeushalmi A. Localized, non-invasive deep microwave hyperthermia for the treatment of prostatic tumors: the first 5 years. Recent Results Cancer Res 1988;107:141-146.

[21] Bellmann K, Jäättelä M, Wissing D, Burkart V, Kolb H. Heat shock protein hsp70 overexpression confers resistance against nitric oxide. FEBS Lett 1996;391(1-2) 185188.

[22] Spiliotis ET, Kinoshita M, Nelson WJ. A mitotic septin scaffold required for Mammalian chromosome congression and segregation. Science 2005;307(5716) 1781-1785.

[23] Robinson CM, Stone AM, Shields JD, Huntley S, Paterson IC, Prime SS. Functional significance of MMP-2 and MMP-9 expression by human malignant oral keratinocyte cell lines. Arch Oral Biol 2003;48(11) 779-786.

[24] Sossey-Alaoui K, Ranalli TA, Li X, Bakin AV, Cowell JK. WAVE3 promotes cell motility and invasion through the regulation of MMP-1, MMP-3, and MMP-9 expression. Exp Cell Res 2005;308(1) 135-145

[25] Jia Y, Zeng ZZ, Markwart SM, Rockwood KF, Ignatoski KM, Ethier SP, Livant DL. Integrin fibronectin receptors in matrix metalloproteinase-1-dependent invasion by breast cancer and mammary epithelial cells. Cancer Res 2004;64(23) 86748681.

[26] Sires UI, Griffin GL, Broekelmann TJ, Mecham RP, Murphy G, Chung AE, Welgus HG, Senior RM. Degradation of entactin by matrix metalloproteinases. Susceptibility to matrilysin and identification of cleavage sites. J Biol Chem1993;268(3) 2069-2074.

[27] Hall C, Nelson DM, Ye X, Baker K, DeCaprio JA, Seeholzer S, Lipinski M, Adams PD. HIRA, the human homologue of yeast Hir1p and Hir2p, is a novel cyclin-cdk2 substrate whose expression blocks S-phase progression. Mol Cell Biol 2001;21(5) 1854-1865.

[28] Murray GI, Duncan ME, O'Neil P, Melvin WT, Fothergill JE. Matrix metalloproteinase-1 is associated with poor prognosis in colorectal cancer. Nat Med 1996;2(4) 461-462. 
[29] Murray GI, Duncan ME, O'Neil P, McKay JA, Melvin WT, Fothergill JE. Matrix metalloproteinase-1 is associated with poor prognosis in oesophageal cancer. J Pathol 1998;185(3) 256-261. 